\title{
Pantocsekiella, a new centric diatom genus based on morphological and ge- netic studies
}

\author{
Éva Ács ${ }^{1 *}$, Eszter ArI ${ }^{2}$, Mónika Duleba ${ }^{1}$, Mirko Dressler ${ }^{3}$, Sergei I. Genkal ${ }^{4}$, \\ Éena JAKÓ ${ }^{5}$, Frederic RIMET ${ }^{6,7}$, Luc EcTOR ${ }^{8} \&$ Keve T. KIss ${ }^{1}$
}
${ }^{1}$ MTA Centre for Ecological Research, Danube Research Institute, Hungarian Academy of Sciences, H-1113 Budapest, Karolina út 29, Hungary; *Corresponding author email: acs.eva@okologia.mta.hu
${ }^{2}$ Eötvös Lóránd University, Faculty of Science, Department of Genetics, H-1117 Budapest, Pázmány Péter sétány $1 / C$, Hungary
${ }^{3}$ University of Rostock, Institute of Bio-Science, Department for Botany and Botanical Garden, Wismarsche Str. 8, D-18057 Rostock, Germany
${ }^{4}$ Institute Biology of Inland Waters, Russian Academy of Sciences, 152742 Borok, Yaroslavl, Nekouz, Russia
${ }^{5}$ Eötvös Lóránd University, Faculty of Science, Department of Plant Systematics, Ecology and Theoretical Biol- ogy, H-1117 Budapest, Pázmány Péter sétány 1/C, Hungary
${ }^{6} I N R A$ - UMR Carrtel, 75 av. de Corzent - BP 511, FR-74203 Thonon les Bains cedex, France
${ }^{7}$ University of Savoie, UMR CARRTEL, FR-73370 Le Bourget du Lac, France
${ }^{8}$ Environmental Research and Innovation Department (ERIN), Luxembourg Institute of Science and Technology (LIST), 41 rue du Brill, L-4422 Belvaux, Luxembourg

The paper is dedicated for $100^{\text {th }}$ death anniversary of the famous Hungarian diatomologist József Pantocsek (1846-1916).

\begin{abstract}
Previous morphological studies showed that the description of the Cyclotella genus was too general and according to new morphological criteria new genera were established based on both recent and fossil taxa (e.g. Discostella, Handmannia, Puncticulata, Tertiarius). Furthermore, previous molecular biological investigations proved that the Cyclotella genus was not monophyletic. Integrating the above mentioned knowledge the former Cyclotella genus has been split into 4 genera (Cyclotella s.s., Discostella, Tertiarius and Lindavia). Based on the position of rimoportula Lindavia genus was formed for involving the species of both the Cyclotella ocellata and C. bodanica lineages. Our morphological and molecular (genetic distance and phylogenetic analyses of $r b c \mathrm{~L}$ and $18 \mathrm{~S}$ rDNA sequences) investigations suggested that "Lindavia/Cyclotella ocellata group" could be raised from the Lindavia as a separate genus. Its distinctive morphological features are the followings: striae unequal in length, central area without areolae. We describe the new genus Pantocsekiella gen. nov. and we transferred several Lindavia taxa into it. We also provide an amended diagnosis for the genus Lindavia.
\end{abstract}

Keywords: Lindavia, morphology, Pantocsekiella gen. nov., $r b c \mathrm{~L}$, taxonomy, $18 \mathrm{~S}$ rDNA

\section{INTRODUCTION}

The genus Cyclotella (BRÉBISSON 1838: 19) including many later described and morphologically diverse $C y$ clotella species was considered as a unitary genus for a long time (see for example KRAMMER \& LANGE-BERTALOT 1991). Within the genus Cyclotella some different morphological groups were previously recognized by several authors: Lowe (1975), McFARLAND \& Collins (1978), Serieyssol (1981), Servant-Vildary (1986), LoGinova (1990). Later, more and more taxonomists believed that the genus description is too general and based on new morphological criteria (e.g. shape and position of rimoportula) several new genera were established on the basis of special characteristics of recent and fossil taxa as well. By this way the genera 
Tertiarius HÅkANSSON et KhURSEvich (1997: 21), Puncticulata HÅKANSSON [2002: 21, 112 - later corrected as Handmannia PERAGallo in HANDMANN (1913: 14) based on priority of description - see more detail in Khursevich \& KocioleK (2012); and as Lindavia (F. Schütt 1899a: 220) De Toni et Forti (1990: 553) regarding both Handmannia and Puncticulata (illegitimate by NAKOv et al. 2015 based on the nomenclatural priority], and Discostella Houk et KLEE (2004: 204205) were established.

Using molecular methods MEDLIN \& KACZMARSKA (2004) clearly showed that the order Centrales was not monophyletic and two main clades were separated. A recent study (AlvERSON et al. 2007) reconstructing the phylogenetic relationships within the order Thalassiosirales showed that the genus Cyclotella (KüTZING) BRÉBISSON (1838: 19) was not monophyletic. In their four-gene phylogenetic tree Cyclotella ocellata PANTOCSEK (1901: 104) and C. bodanica EulEnsteIn in GRUNOW (1878: 126) were clearly separated from the C. meneghiniana KüTZING (1844: 50) group. Jung et al. (2010) pointed out that $C$. bodanica and C. ocellata belonged to Discostella or to a new genus from a genetic point of view, but they did not study them morphologically. Khursevich \& KocioleK (2012) summed up and developed further these morphological groups and a complex diagnosis has been proposed based on the following key characteristics: a) the structure of alveolae, b) the structure, number and location of rimoportula and c) the structure of striae. Based on these criteria 12 morphological groups of Cyclotella taxa were differentiated. The 6th and 7th group has been taken for our paper and only species morphologically similar to Cyclotella ocellata are included. Cyclotella ocellata and C. tripartita HÅKANSSON (1990a: 78) are from group 6 . The following characterization is given for these two species by Khursevich \& KocioleK (2012): "These species have circular valves, with slightly or distinctly radially undulate central area. The latter with a pattern of three to nine larger lacunae (depressions) alternating with papillae (as in C. ocellata), or lacunae and papillae are arranged in 6-12 triangular sectors (as in C. tripartita), .... Near the center at least from one to several (up to 11) valve face fultoportulae with 2 satellite pores... Usually one sessile rimoportula is present in the submarginal zone of the valve face or at the end of the central lamina. Alveolae simple. ..." Cyclotella costei Druart et F. Straub (1988: 182), C. gracilis NikiteEVA et LikHoshway (1994: 350), C. kuetzingiana ThwaItes (1848: 169), C. rossii (GRUNOW) HÅKANSSON (1990b: 266-267), C. schumannii (GrunOw) HÅKansson (1990b: 267) are from group 7. The characterisation is the following: "Valves circular to round, with the central area from nearly flat to more or less transversely undulate, having small and large lacunae (depressions), sometimes they lacking. Besides one to several (up to 5) valve face fultoportulae with 2 satellite pores are present near the center, .... and a single sessile rimoportula is positioned in the submarginal zone of the valve face. ... Striae of equal or unequal length. Alveolae simple. ..."

Previous studies showed that $C$. ocellata and related species form an independent group separately from the $C$. meneghiniana group [C. meneghiniana and related species e.g. C. atomus Hustedt (1937: 143), C. distinguenda Hustedt (1927: 320), C. striata (Kützing) Grunow in Cleve \& Grunow (1880: 119), $C$. stylorum BRIGHTwELl (1860: 96), C. cryptica REIMANN et al. (1963: 82), C. gamma Sovereign (1963: 350)]. Since HÅkansson (2002) drifted Cyclotella bodanica into the genus Puncticulata, Alverson (2014) featured these species as Puncticulata ocellata and P. bodanica (GrunOw in SchNeIDER) HÁKANSSON (2002: 119) in his phylogenetic tree.

NAKOv et al. (2015) transferred C. ocellata and related species together with several other centric diatoms (e.g. Handmannia species) to Lindavia genus on the base of rimoportula position, but they raised that future phylogenetic analysis may support the splitting of Lindavia into some other genera.

We think that morphological features indicate that taxa transferred to Lindavia belong to two different genera. Based on current molecular information Cyclotella/Lindavia ocellata could be the congener of Handmannia bodanica. We used all 18S rRNA gene and $r b c \mathrm{~L}$ sequences and morphological data from all available sources (clonal cultures, environmental samples, isolated cells, public database and previous publication) to show the distance between the two groups. Our results lead to the description of a new genus, Pantocsekiella. The additional aim of this study was to describe the valve morphology and ultrastructure of this new genus.

\section{Material And Methods}

Samples from several sources (Table 1) were subjected to morphological and molecular investigation. The exception was Lake Balaton of which environmental sample was used only in morphological study.

Sampling and sample processing. Phytoplankton samples were dipped $\sim 20 \mathrm{~cm}$ below the water surface. From Lake Geneva, an integrated sample (between 0-20 m depths) was taken above the deepest point of the lake.

Two clonal cultures of Lindavia (Handmannia) radiosa (Ehrenberg) Kociolek et Khursevich emend Genkal (2013: 347) isolated from Lake Stechlin and Lake Nehmitz (Germany) and one culture of a member of the Cyclotella comensis group (identified as Cyclotella costei DRUART et F. Straub 1988: 182-183, on morphological base) from Lake Geneva were established. Clonal cultures were established from single living cells isolated from unfixed material. For culturing conditions see KIstenich et al. (2014). Molecular results of our previous studies (KISTENICH et al. 2014, DuLEBA et al. 2015) were used for comparison; information about details of culturing, molecular methods and phylogenetic analyses are available therein. 
Clonal cultures were divided to two subsamples: one for morphological observation and one for DNA analysis. Subsamples for morphological observations were centrifugated to concentrate the frustules that were cleaned with hydrochloric acid and hydrogen peroxide, subsequently washed in distilled water, filtered through a $3 \mu \mathrm{m}$-mesh polycarbonate membrane, fixed on SEM stubs and coated with gold. The subsamples for DNA analysis were processed in a short time or were preserved in absolute ethanol (Reanal).

Morphological observations. Morphological observations were done by light microscopy (Olympus IX-70). In addition, the fine structure of the diatoms was observed with Zeiss EVO 10 and Hitachi S-2600N scanning electron microscopes. 30 SEM micrographs were taken for morphological analyses from clonal cultures of Handmannia radiosa from Lake Stechlin and Lake Nehmitz.

Molecular methods. Molecular analyses were performed by various authors, therefore methods differred.

Genomic DNA of clone cultures S1 (Lake Stechlin) and NE1 (Lake Nehmitz) was extracted using a QIAGEN DNeasy ${ }^{\circledR}$ Plant Mini kit. For DNA amplification, we used the primers D512for and D978rev (ZIMMERMANN et al. 2011) for partial 18S rDNA regions (V4) and Wawrik for and Wawrik rev (WAWRIK et al. 2002) for partial rbcL DNA. Five mi-

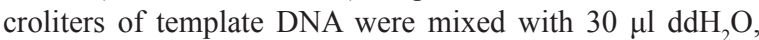
$2.25 \mu \mathrm{l}$ bovine serum albumin (BSA; $10 \mu \mathrm{g} \cdot \mathrm{ml}^{-1}$ ), $2.7 \mu \mathrm{l}$ $\mathrm{MgCl}_{2}(25 \mathrm{mM}), 1.35 \mu \mathrm{d}$ dNTPs $(10 \mathrm{mM}), 1.8 \mu \mathrm{l}$ of forward and $1.8 \mu \mathrm{l}$ of reverse primer $(10 \mu \mathrm{M}), 4.5 \mu \mathrm{l}$ polymerase buffer $(10 \times)$ and $0.6 \mu \mathrm{l}$ Taq DNA polymerase $\left(5 \mathrm{U} \mu \mathrm{l}^{-1}\right)$ for the polymerase chain reaction (PCR). Values in parentheses indicate the original concentrations of ingredients. PCR programmes were used according to ZiMMERMANN et al. (2011) and WAWRIK et al. (2002). PCR products were visualized in $2 \%$ agarose gel and relevant bands were cut out. Gel extraction and purification of PCR products was conducted by applying a QIAquick ${ }^{\circledR}$ Gel Extraction kit. Final products were sequenced twice (forward and reverse) with an $\mathrm{ABI} / \mathrm{Hitachi}$ 3130xl Genetic Analyzer (Tokyo) using Sanger sequencing (SANGER et al. 1974) with PCR primers as sequence primers.

To extend sequences of the culture S1, additional PCRs were performed using $1 \mathrm{~F}$ and $1528 \mathrm{R}$ primers (MEDLIN et al. 1988) for 18S rDNA and rbcL66F (ALVERSON et al. 2007) and dp7R (DAugbJerg \& ANDERSEN 1997). For $r b c \mathrm{~L}$ reaction, the mixture contained $1.25 \mathrm{U}^{\text {DreamTaq }}{ }^{\mathrm{TM}}$ DNA Polymerase (Thermo Scientific), $200 \mathrm{mM}$ of each deoxynucleoside triphosphate (Fermentas), 1X DreamTaq Buffer (Thermo Scientific), $0.325 \mu \mathrm{M}$ of each primer, $1 \mu$ template in a total volume of $25 \mu$ l. PCR amplification used the following cycles: initial denaturation at $98{ }^{\circ} \mathrm{C}$ for $4 \mathrm{~min}$, 32 cycles at $94{ }^{\circ} \mathrm{C}$ for $1 \mathrm{~min}, 56^{\circ} \mathrm{C}$ for $30 \mathrm{sec}, 72{ }^{\circ} \mathrm{C}$ for $1.5 \mathrm{~min}$, and a final extension at $72{ }^{\circ} \mathrm{C}$ for $10 \mathrm{~min}$. For $18 \mathrm{~S}$ rDNA reaction, the mixture contained $0.05 \mathrm{U}$ HotMaster Taq Polymerase (5Prime), $0.2 \mathrm{mM}$ of each deoxynucleoside triphosphate (5Prime), 1X DreamTaq Buffer (5Prime), $0.2 \mu \mathrm{M}$ of each primer, $1 \mu \mathrm{l}$ template in a total volume of $50 \mu \mathrm{l}$. The heat protocol of this reaction was the following: initial denaturation at $94{ }^{\circ} \mathrm{C}$ for $5 \mathrm{~min}, 35$ cycles at $94{ }^{\circ} \mathrm{C}$ for $1 \mathrm{~min}, 58$ ${ }^{\circ} \mathrm{C}$ for $2 \mathrm{~min}, 72{ }^{\circ} \mathrm{C}$ for $2 \mathrm{~min}$, and a final extension at $72{ }^{\circ} \mathrm{C}$ for $10 \mathrm{~min}$. Sequencing reactions with $1 \mathrm{~F}, 1528 \mathrm{R}$ (MEDLIN et al. 1988) Sk-155R (DulebA et al. 2014) for $18 \mathrm{~S}$ rDNA and rbcL66F (Alverson et al. 2007) and dp7R (DAUGBJERG \& ANDERSEN 1997) for $r b c L$ and capillary electrophoreses were performed by Biomi Ltd. 
Cells were harvested from the $C$. costei culture by centrifugation. After lysing the cells, nucleic acids were co-precipitated using GenEluteTM-LPA (Sigma-Aldrich) according to the Manufacturer's instructions, and dissolved in TE buffer. Two gene fragments were amplified in PCR: partial $r b c \mathrm{~L}$ and $18 \mathrm{~S}$ rDNA. All PCRs were performed using the $1 \mathrm{~F}$ and 1528R primers (MedLin et al. 1988) for 18S rDNA, DPrbcL1 and DPrbcL7 primers (DAugBJerg \& ANDERsen 1997) for $r b c \mathrm{~L}$ and according to the authors' specifications in a PCR thermal cycler (T personal, Biometra, Göttingen, Germany). Additional internal sequencing primers (528F for $18 \mathrm{~S}$ rDNA, Elwood et al. 1985, NDrbcL6, DAUGBJerg \& ANDERSEN 1997, $15 \mathrm{R}, 16 \mathrm{~F}$ for $r b c \mathrm{~L}$, Jones et al. 2005) were used to retrieve the complete sequences of $r b c \mathrm{~L}$. Sanger sequencing was performed by GATC (Konstanz, Germany).

Phylogenetic analysis. 18S rDNA and $r b c \mathrm{~L}$ sequences were aligned to sequences in National Center for Biotechnology Information (NCBI) GenBank database using basic local alignment search tool (BLAST, AltschUl et al. 1990) in order to find sequences showing highest similarity with them. The search was performed in the Nucleotide collection database (nr/nt) using Standard Nucleotide BLAST program, megablast (highly similar sequences) algorithm with the de- fault parameter settings.

Beside sequences from samples listed in Table 1, additional, unpublished and published sequences were used (Table 2). These included sequences of a clonal culture from Lake Balaton.

Within and between groups mean uncorrected $\mathrm{p}-$ distance values were calculated with MEGA 6 (TAMURA et al. 2013). Sequences from the same genus were treated as a group.

The $r b c \mathrm{~L}$ sequences were aligned by codon to sequences downloaded from GenBank using Clustal W implemented in MEGA 6 (TAMURA et al. 2013). The 18S rDNA sequences were aligned by secondary structure using SILVA Incremental Aligner (SINA, PruesSe et al. 2012, available at http://www.arb-silva.de/aligner/). 'Find best DNA models' option in MEGA 6 software was used to determinate the most appropriate substitution model for DNA sequence evolution of each gene. The models proposed by the software based on Bayesian Information Criterion were Tamura-Nei model with gamma distribution for 18S rDNA (TAMURA \& Ner 1993) and General Time Reversible (GTR) model with gamma distribution and invariant sites for $r b c \mathrm{~L}$ (RoDRÍGUEZ et al. 1990). Maximum likelihood phylogenetic analyses were run on single-gene datasets in MEGA 6 (TAMURA et

Table 2. Additional sequences used in phylogenetic analyses.

\begin{tabular}{|c|c|c|c|}
\hline Species & Culture & Sampling site & Reference \\
\hline Cyclostephanos delicatus & MD 11 & Lake Ziegelinnen, Schwerin (Germany) & unpublished \\
\hline Cyclotella comensis-group & NE 3 & Lake Nehmitz, Brandenburg (Germany) & unpublished \\
\hline Cyclotella comensis-group & JO 2 & Jonsvannet (Trondheim, Norway) & unpublished \\
\hline $\begin{array}{l}\text { Cyclotella comensis-group } \\
\text { (C. comensis) }\end{array}$ & BG 2 & Lake Baggersee (Austria) & Kistenich et al. (2014) \\
\hline $\begin{array}{l}\text { Cyclotella comensis-group } \\
\text { (C. costei) }\end{array}$ & $\mathrm{F} 1$ & Lake Fernsteinsee (Austria) & Kistenich et al. (2014) \\
\hline $\begin{array}{l}\text { Cyclotella comensis-group } \\
\text { (C. costei) }\end{array}$ & GUL & Lake Gültzsee (Germany) & Kistenich et al. (2014) \\
\hline $\begin{array}{l}\text { Cyclotella comensis-group } \\
\text { (C. pseudocomensis) }\end{array}$ & HS1 & Lake Hausse (Germany) & Kistenich et al. (2014) \\
\hline Cyclotella distinguenda-group & BG 3 & Lake Baggersee (Austria) & unpublished \\
\hline Cyclotella meneghiniana-group & W 8 & Warnow, Rostock (Germany) & unpublished \\
\hline Cyclotella ocellata & BA0 & Balaton (Hungary) & unpublished \\
\hline Cyclotella ocellata & KK4 & Kiesgrube-Krugsdorf & Kistenich et al. (2014) \\
\hline Cyclotella ocellata & & Lake Dunaharaszti (Hungary) & Duleba et al. (2015) \\
\hline Cyclotella ocellata & & Lake Himód (Hungary) & Duleba et al. (2015) \\
\hline Cyclotella ocellata & & Lake Visovac (Croatia) & DuLEBA et al. (2015) \\
\hline $\begin{array}{l}\text { Lindavia (Handmannia) radiosa- } \\
\text { group }\end{array}$ & DM 1 & Demenzsee, OVP (Germany) & unpublished \\
\hline Stephanodiscus alpinus & SN 3 & Schweriner Innensee (Seewarte) (Germany) & unpublished \\
\hline Stephanodiscus medius & MD 9 & Lake Ziegelinnen, Schwerin (Germany) & unpublished \\
\hline Stephanodiscus parvus-group & HSP 7 & Lake Hohen Sprenzer (Germany) & unpublished \\
\hline Stephanodiscus parvus-group & BA 2 & Lake Balaton (Hungary) & unpublished \\
\hline
\end{tabular}


al. 2013). Bootstrap test was performed in 500 replicates. Bayesian analyses were run on single and combined datasets. Data were partitioned by genes. Posterior probability of distribution was estimated using Metropolis-coupled Markov Chain Monte Carlo (MCMC) as implemented in MrBayes 3.2 (RonQuist et al. 2012). Two runs were started in which a cold and three heated chains were run. Samples were taken in every $100^{\text {th }}$ cycle, $25 \%$ of the samples were discarded as burnin. The average standard deviation of split frequencies across independent analyses was used as convergence diagnostic, the analysis was continued until this value decreased below 0.01 or it was between 0.01 and 0.02 , but it fluctuated around a value. For all parameters potential scale reduction factor (PSRF) was close to 1, average ESS values were higher than minimum ESS values in all analyses.

\section{Results}

\section{Morphological investigation}

Two clonal cultures of Lindavia (Handmannia) radiosa isolated from Lake Stechlin (Figs 1, 2) and Lake Nehmitz (Figs 3, 4) were newly investigated. Based on these cultures, frustules are disc-shaped; valves are circular, 6-12.9 $\mu \mathrm{m}$ in diameter. The central area of the valve face can be relatively small or large, not depending on the diameter; it is flat or slightly concentrically undulate, convex or concave, externally smooth to colliculate, sometimes radially wrinkled. Striation is fine, 7-9 striae are in $10 \mu \mathrm{m}$ and unequal in length, central area is polygonal. The striation pattern has a complex alveolar structure; the internal alveolar openings are with alternating 3-7 thin costae between 2 thickened ribs. Each thickened costa bears a marginal fultoportula near the valve margin with two satellite pores positioned laterally. Areolae and central fultoportulae are arranged in radial rows or scattered. The central fultoportulae, externally with a small opening and internally with three satellite pores, are scattered among areolae or are inserted within the radial rows of areolae in the form of 1 ring. Isolated areolae are often present in the valve centre. 1-2 rimoportulae are situated on the valve face in the submarginal zone. The external openings are situated on a hyaline rib formed at the end of shortened stria internally with a sessile labium with a radial oblique or circumferential slit.

\section{Genetic investigation}

From the clonal culture of $C$. costei full length of $r b c \mathrm{~L}$ (1500 nt) and almost full length of 18S rDNA (1699 nt) were acquired. From the two Lindavia (Handmannia) radiosa cultures first partial sequences were gained [L. radiosa cultures: $r b c \mathrm{~L}: 506$ nucleotides (nt), $18 \mathrm{~S}$ rDNA: 391 and $399 \mathrm{nt}$ ] but later sequences of the culture from Lake Stechlin were extended ( $r b c \mathrm{~L}: 1407 \mathrm{nt}$, 18S rDNA: $1667 \mathrm{nt}$ ).

BLAST: According to the BLAST search $r b c \mathrm{~L}$ sequence of $C$. costei from Lake Geneva showed the highest similarity with $C$. ocellata strain LB8 (99\%, 1427 identical nucleotides at the compared 1438 sites; our sequence proved to be too long compared to the ones in GenBank). Its $18 \mathrm{~S}$ rDNA sequence also showed 99\% similarity with C. ocellata (1685 identical nucleotides and two gaps at 1699 sites), but reached higher scores (99\% similarity, 1688/1699 nt with two gaps) with a group of Stephanodiscus EHRENBERG (1845: 72) and Cyclostephanos Round ex THeriot et al. (1987a: 346) sequences.

There was not any difference between the two cultures of Lindavia (Handmannia) radiosa in the compared regions of either $18 \mathrm{~S}$ rDNA or $r b c \mathrm{~L}$. According to the BLAST search extended $r b c \mathrm{~L}$ sequence of the L. radiosa from Lake Stechlin showed 98\% similarity with four Stephanodiscus sequences (1372-1375 identical nt at 1407 sites) and Lindavia (Handmannia) bodanica (EULENSTEIN ex GRUNOW) NAKOv et al. (2015: 254) J98-1 strain (1371 identical nucleotides at 1404 sites). The $18 \mathrm{~S}$ rDNA sequence of $L$. radiosa from Lake Stechlin showed 99\% similarity (1642-1652 identical nucleotides and one gap were at 1667 sites) with several Stephanodiscus [including a Stephanodiscus strain later renamed as Praestephanos triporus (Genkal et G.V. Kuzmin) Tuj et J.-S. Ki in Tuji et al. (2014: 135)] and Cyclostephanos sequences and with L. bodanica J98-1 (1648 identical nucleotides and one gap at 1667 sites) and C. ocellata LB8 (1645 identical nucleotides and one gap at 1667 sites).

The $\mathrm{p}$-distance values were calculated on two datasets. First, both short and long sequences (those of $C$. costei and L. radiosa cultures and the ones listed in Table 1) were also involved. Second, the short sequences were excluded, thus much longer regions could be compared. In general, the $\mathrm{p}$-distance values were lower in longer region of the fewer sequences than in shorter region of the more sequences.

Mean distances within groups: Based on both of all and also on only the long $r b c \mathrm{~L}$ the mean distance within the Pantocsekiella genus (all sequences: 0.29\%, only the long ones: $0.84 \%$ ) was lower than within other groups (all sequences: $0.96-6.48 \%$, only the long ones: $0.95-7.50 \%)$.

Based on all 18S rDNA the mean distance of this group $(0.49 \%)$ was relatively low value, two genera [Bacterosira Gran (1900: 114), Stephanodiscus, Cyclostephanos] showed lower values (0-0.46\%), five genera [Shionodiscus, Lindavia (Handmannia), Discostella, Skeletonema Greville (1865: 43), Cyclotella] showed higher values $(0.55-2.80 \%)$. Considering only the long sequences, Pantocsekiella had higher value $(0.58 \%)$ than Stephanodiscus, Bacterosira and Cyclostephanos $(0.11-0.23 \%)$ and lower than Shionodiscus, Discostella, Lindavia, Cyclotella and Skeletonema (0.96-2.12\%).

Mean distances between groups: The $r b c \mathrm{~L}$ showed 
higher genetic distance between the proposed genus Pantocsekiella and Lindavia (Handmannia) than Stephanodiscus-Lindavia (Handmannia), Stephanodiscus-Cyclostephanos distances with and without short sequences. Based on $18 \mathrm{~S}$ rDNA the Pantocsekiella-Lindavia (Handmannia) distance was higher than Cyclostephanos-Pantocsekiella, Stephanodiscus-Pantocsekiella, Cyclostephanos-Stephanodiscus distance in both analyses (these distances are indicated with italic numbers on Tables 3 and 4).

Phylogenetic analyses: To improve the reliability of phylogenetic trees short sequences were excluded from these analyses. The phylogenetic tree based on single (Supplementary Figs 1-4) and combined datasets (Fig. 5) showed that the Pantocsekiella ocellata and P. comensis sequences formed a cluster clearly separated from the clade constituted by the L. radiosa and $L$. bodanica sequences.

The genus Pantocsekiella appeared to be monophyletic on all trees, therefore establishment of a new genus is reasonable. The closest relative of the Pantocsekiella genus was Lindavia (Handmannia) (Fig. 5, Supplementary Figs 1-4).

\section{New genus description}

Pantocsekiella K.T. KIss et Ács, gen. nov.

Diagnosis: Frustules are disc-shaped, solitary, seldom in short chains. Valves circular or slightly quadrangular, the valve face divided into a polygonal central area and a striated marginal one. The polygonal central area is more or less flat or radially undulate (3-5 undulation) or slightly tangentially undulated. The undulated forms with a pattern of three or more small or large alternating lacunae with or without papillae; this pattern is arranged in 6 or more triangular sectors, or the central area with numerous randomly located lacunae and small punctae which do not penetrate the cell wall. The central area can be relatively small or large, not depending on the diameter. The marginal part of the valve is structured by alveolate striae externally, separated by hyaline strips, striae are straight, unequal in length and a few of them are bifurcated. Simple alveolae are present within the marginal area internally. The inner aperture of the alveolae can be round or elongated. Costae are usually equal in length but those bearing a fultoportula are often shorter. The valve has one or a few rimoportulae situated in the submarginal zone on the costa
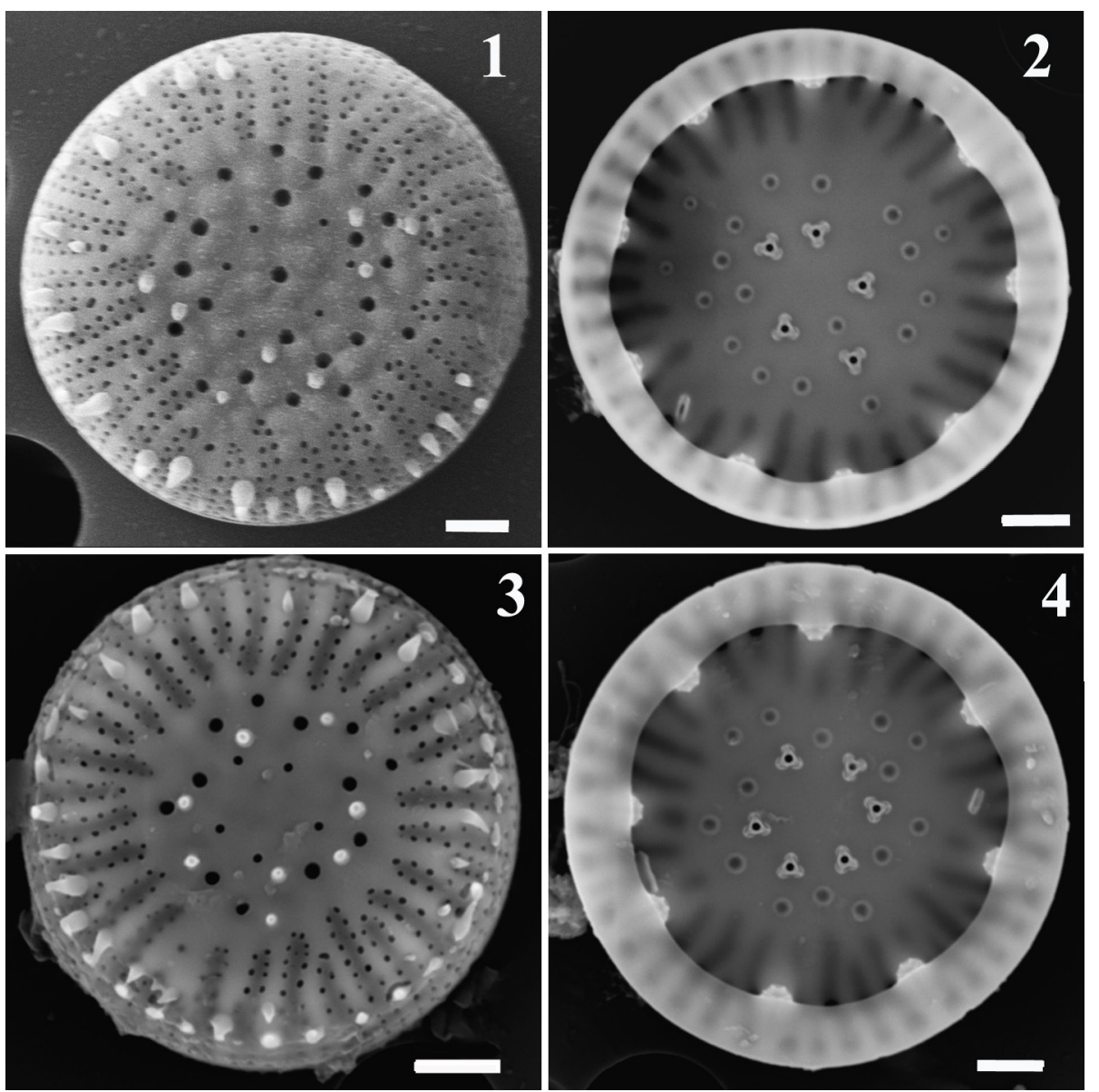

Figs 1-4. SEM micrographs of Lindavia radiosa: (1-2): culture isolated from Lake Stechlin; (3-4) culture isolated from Lake Nehmitz; (1, 3 ) external view of valve face, striae different in length, areolae in center scattered, valve face fultoportulae in ring; spinules on margin and granules in centre; $(2,4)$ internal view of valve, areolae in center scattered, valve face fultoportulae in ring. Scale bar $1 \mu \mathrm{m}$. 
or just below it (sessile internally and round aperture externally); the orientation of the lip varies. Generally, every third to fifth interstria bears a marginal fultoportula but it may occur on each to every 6 th interstria. Their internal openings are surrounded by two satellite pores. Valve face fultoportulae (VFP: 1-4) are usually surrounded by two (1-3) satellite pores. In many cases the external openings of VFP are very difficult to observe, because many valves have some punctae irregularly arranged in the central part. Small granules are frequently observed on the interstriae near the margin and found sporadically on the whole valve face.

Cyclotella species differ from Pantocsekiella in arrangement of marginal fultoportulae and rimoportula(e). Rimoportula(e) of Cyclotella situated in the ring of marginal fultoportulae and striae (costae) are equal in length.

Lindavia species differ from Pantocsekiella in structure of central area. Lindavia species have areolae in central area and complex alveolar structure, Pantocsekiella and Cyclotella never.

Type species: Cyclotella ocellata PANTOCSEK (1901), Die Kieselalgen oder Bacillarien des Balaton, p. 104, pl. 15 , fig. 318 .

Etymology: The new genus has been named after József Pantocsek, the worldwide known famous Hungarian diatomologist, who originally described Cyclotella ocellata.

\section{Systematic emplacement:}

Class Coscinodiscophyceae Round et CRAWFORD Subclass Archaegladiopsophycidae NiKolaEv et HARWOOD

Order Stephanodiscales Nikolaev et Harwood

Family Stephanodiscaceae GLESER et MAKAROVA

Genus Pantocsekiella K.T. KIss et Ács gen. nov.

Typus generis: Pantocsekiella ocellata (PANTOCSEK) K.T. KIss et Ács, comb. nov.

\section{Pantocsekiella ocellata (PANTOCSEK) K.T. KISS et Ács, comb. nov. \\ Basionym: Cyclotella ocellata PANTOCSEK 1901, Die Kieselalgen oder Bacillarien des Balaton, p 104, pl. 15, fig. 318 \\ Synonyms: Cyclotella crucigera PANTOCSEK 1901, p. 104, pl. 15, fig. 325; Cyclotella kuetzingiana var. planetophora FRICKE in SCHMIDT 1900, pl. 222, figs. 9-12; Cyclotella tibetana HustedT 1922a, p. 117, pl. 9, fig. 19; Cyclotella trichonidea var. parva ЕсоNOMOU-AмILLI 1979, p. 470, figs. 21-25; Lindavia ocellata (PANtocseK) NAKov et al. 2015 , p. 256 .}

General description: Frustules are disc-shaped, valves are circular, rarely slightly quadrangular (in Lake Visovac). The polygonal central area of valve face is more or less flat or radially undulate, 3-5 undulation depending on number of orbiculi depressi (OD, Figs 6-11). Usually, the structure of the central area and marginal area of the valve surface is different on valves with OD but frequently seems almost homogenous on small valves without OD. A slight tangential undula- tion of central area can be seen on quadrangular and triangular valves at tilted position (Fig. 6). The valve face has OD and papillae zero (Fig. 10) to five, besides OD there are relatively small punctae zero to eleven in number. The central part of the valve can be relatively small or large $(2.5-7.3 \mu \mathrm{m})$, not depending on the diameter and contains different-sized and spaced colliculate protuberances. The marginal part of the valve is structured by alveolate striae externally, separated by hyaline strips, striae are straight, unequal in length and a few of them are bifurcated (Figs 7,9). Small granules are frequently observed on the interstriae near the margin and found sporadically on the striae (Figs 6, 9, 11) or on the whole valve face. Simple alveolae are present within the marginal area internally. The inner aperture of the alveolae can be round or elongated. Costae are usually equal in length but those bearing a fultoportula are often shorter (Figs 12-14). The valve has one or a few rimoportulae situated in the submarginal zone on the costa or just below it (sessile internally and round aperture externally); the orientation of the lip varies. Generally, every third to fifth interstria bears a marginal fultoportula (MFP) but it may occur on each to every 6 th interstria. Their internal openings are surrounded by two satellite pores. Valve face fultoportulae (VFP: $1-4$, Figs 12,13$)$ are usually surrounded by two (1-3) satellite pores (Figs 12-14). In many cases the external openings of VFP are very difficult to observe, because many valves have some punctae irregularly arranged in the central area.

Type locality: Lake Balaton, Hungary.

\section{Nomenclatural changes}

New nomenclatural combinations suggested in connection with the proposed new genus Pantocsekiella are proposed.

\section{Pantocsekiella andancensis (A. EHRLICH) K.T. KISS, ECTOR et Ács, comb. nov. \\ Basionym: Cyclotella andancensis A. EHrLICH 1966, Contribution à l'étude des gisements volcano-lacustres à diatomées de la région de Rochessauve et de Saint-Bauzile (Ardèche). - Bulletin de la Société Géologique de France, ser. 7, 8, p. 316, pl. 5, figs. 11-13. \\ Synonyms: Cyclotella andancensis var. bauzilensis SERIEYSSOL 1981, p. 29, pl. 4, figs. 22-28; Cyclotella andancensis var. bipolaira SERIEYSSOL 1981, p. 30, pl. 5, figs. 29-36.}

Type locality: Deposits of the Montagne d'Andance, Saint-Bauzile, Ardèche, France.

Pantocsekiella arctica (GenKal et KhaRitonov) K.T. Kiss, Genkal et Ács, comb. nov.

Basionym: Cyclotella arctica GenKAL et KHARITONov 1996, Cyclotella arctica (Bacillariophyta) - a new species from Lake El'gygytgyn (Chukotka Peninsula). - Botanicheskii Zhurnal 81, p. 69, pl. 1, figs. $1-8$, pl. 2, figs. $1-3$.

Synonym: Lindavia arctica (Genkal et Kharitonov) Nakov et al. 2015, p. 254.

Type locality: Lake El'gygytgyn, Chukchi Peninsula, 


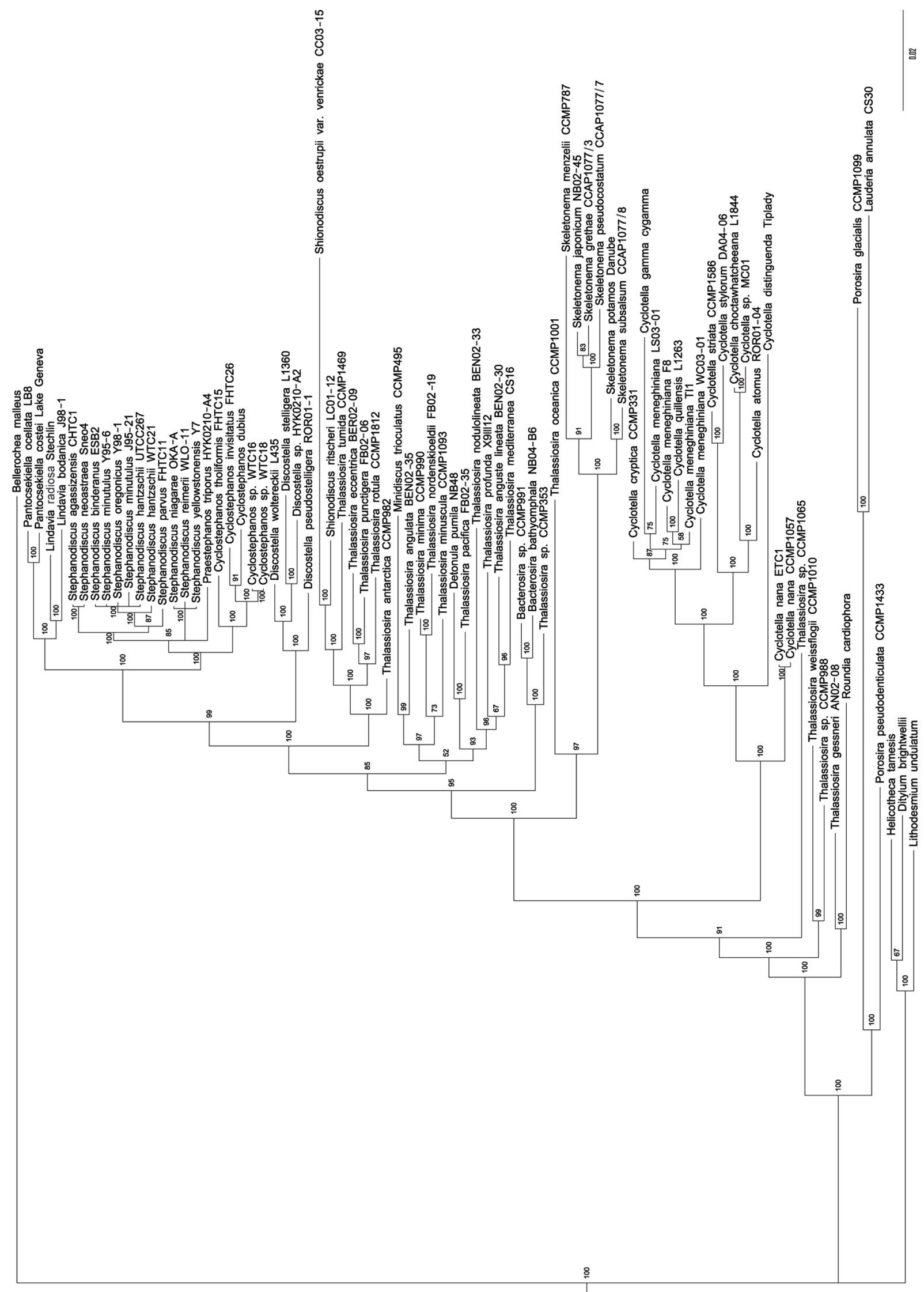

Fig. 5. Bayesian inferred phylogenetic tree of combined data constructed Tamura-Nei model (TAMURA \& NEI 1993) with gamma distribution for $18 \mathrm{~S}$ rDNA and and GTR model (RoDRíGuEz et al. 1990) with gamma distribution and invariant sites for $r b c \mathrm{~L}$. In two runs a cold and three heated chains were run for 700000 generations. The average standard deviation of split frequencies across independent analyses was 0.010198 in the last generation. Posterior probability values are indicated at the nodes. Scale bar represents 0.05 substitutions per site. 
Table 3. Mean p-distances (expressed in percentage) of $r b c \mathrm{~L}$ sequences between genera as groups. First number is the mean distance of all sequences, the comparison involved 415 positions. The second number in parentheses represents the mean distance without short sequences, 1306 positions were included in the analysis. The number in parentheses after genus name indicates the number of species included in each group: the first number in the analysis with all sequences, the second number in analysis without short ones. Intergeneric distances lower than Pantocsekiella-Lindavia distance in both analyses are in italic.

\begin{tabular}{|c|c|c|c|c|c|c|c|c|}
\hline & 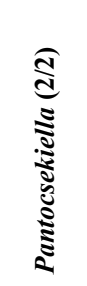 & 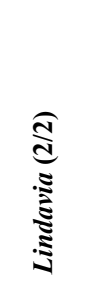 & 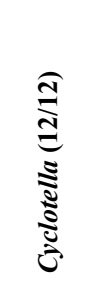 & 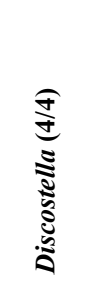 & 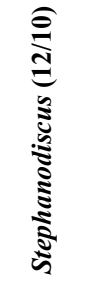 & 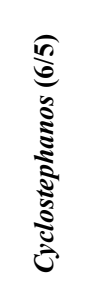 & 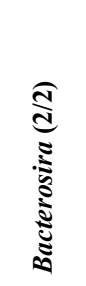 & 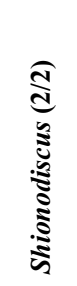 \\
\hline Lindavia $(2 / 2)$ & $\begin{array}{c}4.30 \\
(3.41)\end{array}$ & & & & & & & \\
\hline Cyclotella (12/12) & $\begin{array}{c}8.48 \\
(6.47)\end{array}$ & $\begin{array}{c}7.60 \\
(6.25)\end{array}$ & & & & & & \\
\hline Discostella (4/4) & $\begin{array}{c}6.50 \\
(5.26)\end{array}$ & $\begin{array}{c}5.51 \\
(5.03)\end{array}$ & $\begin{array}{c}8.18 \\
(6.65)\end{array}$ & & & & & \\
\hline Stephanodiscus $(12 / 10)$ & $\begin{array}{c}4.95 \\
(3.44)\end{array}$ & $\begin{array}{c}3.45 \\
(2.79)\end{array}$ & $\begin{array}{c}7.51 \\
(6.01)\end{array}$ & $\begin{array}{c}4.74 \\
(4.28)\end{array}$ & & & & \\
\hline Cyclostephanos (6/5) & $\begin{array}{c}6.36 \\
(4.02)\end{array}$ & $\begin{array}{c}4.38 \\
(3.25)\end{array}$ & $\begin{array}{c}7.70 \\
(5.92)\end{array}$ & $\begin{array}{c}5.00 \\
(4.16)\end{array}$ & $\begin{array}{c}3.42 \\
(2.17)\end{array}$ & & & \\
\hline Bacterosira (2/2) & $\begin{array}{c}5.81 \\
(5.90)\end{array}$ & $\begin{array}{c}5.48 \\
(5.86)\end{array}$ & $\begin{array}{c}8.45 \\
(7.15)\end{array}$ & $\begin{array}{c}5.30 \\
(5.26)\end{array}$ & $\begin{array}{c}4.34 \\
(5.22)\end{array}$ & $\begin{array}{c}3.95 \\
(4.95)\end{array}$ & & \\
\hline Shionodiscus (2/2) & $\begin{array}{l}10.12 \\
(7.48)\end{array}$ & $\begin{array}{c}8.98 \\
(7.35)\end{array}$ & $\begin{array}{l}10.43 \\
(7.82)\end{array}$ & $\begin{array}{c}9.58 \\
(7.30)\end{array}$ & $\begin{array}{c}8.98 \\
(7.16)\end{array}$ & $\begin{array}{c}9.22 \\
(7.23)\end{array}$ & $\begin{array}{c}8.73 \\
(7.04)\end{array}$ & \\
\hline Skeletonema (6/6) & $\begin{array}{c}8.44 \\
(6.29)\end{array}$ & $\begin{array}{c}7.31 \\
(6.04)\end{array}$ & $\begin{array}{c}8.87 \\
(6.96)\end{array}$ & $\begin{array}{c}7.00 \\
(5.79)\end{array}$ & $\begin{array}{c}6.95 \\
(5.60)\end{array}$ & $\begin{array}{c}6.23 \\
(5.39)\end{array}$ & $\begin{array}{c}5.86 \\
(5.65)\end{array}$ & $\begin{array}{c}10.36 \\
(7.80)\end{array}$ \\
\hline
\end{tabular}

Table 4. Mean p-distances (expressed in percentage) of $18 \mathrm{~S}$ rDNA sequences between genera as groups. First number is the mean distance of all sequences, the comparison contained 360 positions. The second number in parentheses represents the mean distance without short sequences, 1564 positions were involved in the analysis. The number in parentheses after genus name indicates the number of species included in each group: the first number in the analysis with all sequences, the second number in analysis without short ones. In the case of $C y c l o t e l l a$ $18 \mathrm{~S}$ rDNA sequence of $C$. stylorum was not available hence 11 species could be evaluated in contrast the 12 species in the analysis of $r b c \mathrm{~L}$. Intergeneric distances lower than Pantocsekiella-Lindavia distance in both analyses are in italic.

\begin{tabular}{|c|c|c|c|c|c|c|c|c|}
\hline & 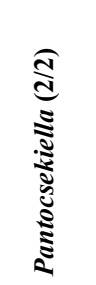 & 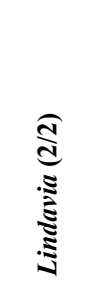 & 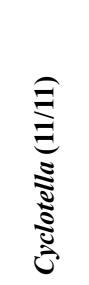 & 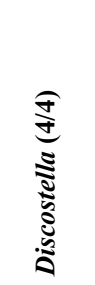 & 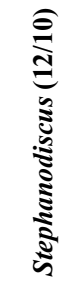 & 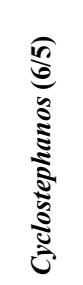 & 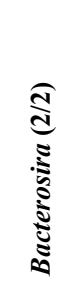 & 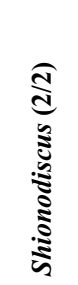 \\
\hline Lindavia $(2 / 2)$ & $\begin{array}{c}1.76 \\
(1.13)\end{array}$ & & & & & & & \\
\hline Cyclotella (11/11) & $\begin{array}{c}7.70 \\
(4.87)\end{array}$ & $\begin{array}{c}8.66 \\
(5.21)\end{array}$ & & & & & & \\
\hline Discostella (4/4) & $\begin{array}{c}1.91 \\
(1.81)\end{array}$ & $\begin{array}{c}3.26 \\
(2.28)\end{array}$ & $\begin{array}{c}8.20 \\
(4.73)\end{array}$ & & & & & \\
\hline Stephanodiscus $(12 / 10)$ & $\begin{array}{c}1.10 \\
(0.85)\end{array}$ & $\begin{array}{c}1.39 \\
(1.21)\end{array}$ & $\begin{array}{c}7.79 \\
(4.54)\end{array}$ & $\begin{array}{c}2.31 \\
(1.57)\end{array}$ & & & & \\
\hline Cyclostephanos (6/5) & $\begin{array}{c}1.25 \\
(0.89)\end{array}$ & $\begin{array}{c}1.55 \\
(1.21)\end{array}$ & $\begin{array}{c}7.89 \\
(4.54)\end{array}$ & $\begin{array}{c}2.45 \\
(1.56)\end{array}$ & $\begin{array}{c}0.33 \\
(0.27)\end{array}$ & & & \\
\hline Bacterosira (2/2) & $\begin{array}{c}2.52 \\
(1.93)\end{array}$ & $\begin{array}{c}2.71 \\
(2.24)\end{array}$ & $\begin{array}{c}6.94 \\
(4.82)\end{array}$ & $\begin{array}{c}2.78 \\
(2.22)\end{array}$ & $\begin{array}{c}1.94 \\
(1.37)\end{array}$ & $\begin{array}{c}2.18 \\
(1.56)\end{array}$ & & \\
\hline Shionodiscus (2/2) & $\begin{array}{c}2.52 \\
(1.79)\end{array}$ & $\begin{array}{c}2.71 \\
(2.13)\end{array}$ & $\begin{array}{c}7.89 \\
(4.77)\end{array}$ & $\begin{array}{c}2.60 \\
(2.10)\end{array}$ & $\begin{array}{c}1.94 \\
(1.37)\end{array}$ & $\begin{array}{c}2.18 \\
(1.46)\end{array}$ & $\begin{array}{c}1.11 \\
(1.15)\end{array}$ & \\
\hline Skeletonema (6/6) & $\begin{array}{c}7.00 \\
(5.48)\end{array}$ & $\begin{array}{c}8.10 \\
(5.96)\end{array}$ & $\begin{array}{c}10.46 \\
(7.51)\end{array}$ & $\begin{array}{c}6.94 \\
(5.53)\end{array}$ & $\begin{array}{r}7.54 \\
(5.53) \\
\end{array}$ & $\begin{array}{c}7.75 \\
(5.68) \\
\end{array}$ & $\begin{array}{c}5.69 \\
(5.27) \\
\end{array}$ & $\begin{array}{c}6.44 \\
(5.45) \\
\end{array}$ \\
\hline
\end{tabular}


Russia.

Pantocsekiella azigzensis (FLOWER et al.) K.T. KISS et Ács, comb. nov.

Basionym: Cyclotella azigzensis Flower et al. 1990, A new species of Cyclotella, C. azigzensis sp. nov., described from modern material collected from upland lakes in Morocco. - Diatom Research 5, p. 254, figs. 1-12, 16-23

Synonym: Lindavia azigzensis (FLower et al.) NAKov et al. 2015, p. 254

Type locality: Lake (Aguelmane) Azigza, Morocco.

Pantocsekiella bavarica (KLEe, Rol. SCHMidT et Jens Müller) K.T. KISS et Ács, comb. nov.

Basionym: Cyclotella bavarica KleE, Rol. Schmidt et Jens MÜlleR 1993, Alleröd diatom assemblages in prealpine hardwater lakes of Bavaria and Austria as preserved by the Laacher See eruption event. - Limnologica 23, p. 135, figs. 6 a-1, 7 a-e.

Synonym: Lindavia bavarica (KLeE, Rol. Schmidt et Jens Müller) NAKOv et al. 2015, p. 254.
Type locality: Lake Starnberg, Bavaria, Germany.

Pantocsekiella chantaica (KuZMINA et GENKAL) K.T. Kiss, Genkal et Ács, comb. nov.

Basionym: Cyclotella chantaica Kuzmina et Genkal 1989, On new species of genus Cyclotella Kütz. (Bacillariophyta). - Biology of Inland Waters 84, p. 9, figs. 1-14.

Synonym: Lindavia chantaica (Kuzmina et GenKal) Nakov et al. 2015, p. 254.

Type locality: River Chantaika, Siberia, Russia.

\section{Pantocsekiella comensis (Grunow in VAN HeURCK)} K.T. KIss et Ács, comb. nov.

Basionym: Cyclotella comensis Grunow in VAN Heurck 1882, Synopsis des Diatomées de Belgique. - Atlas, pl. 93, figs. 16, 17.

Synonym: Lindavia comensis (Grunow in Van Heurck) Nakov et al. 2015, p. 254 .

Type locality: Lake Como, Italy.
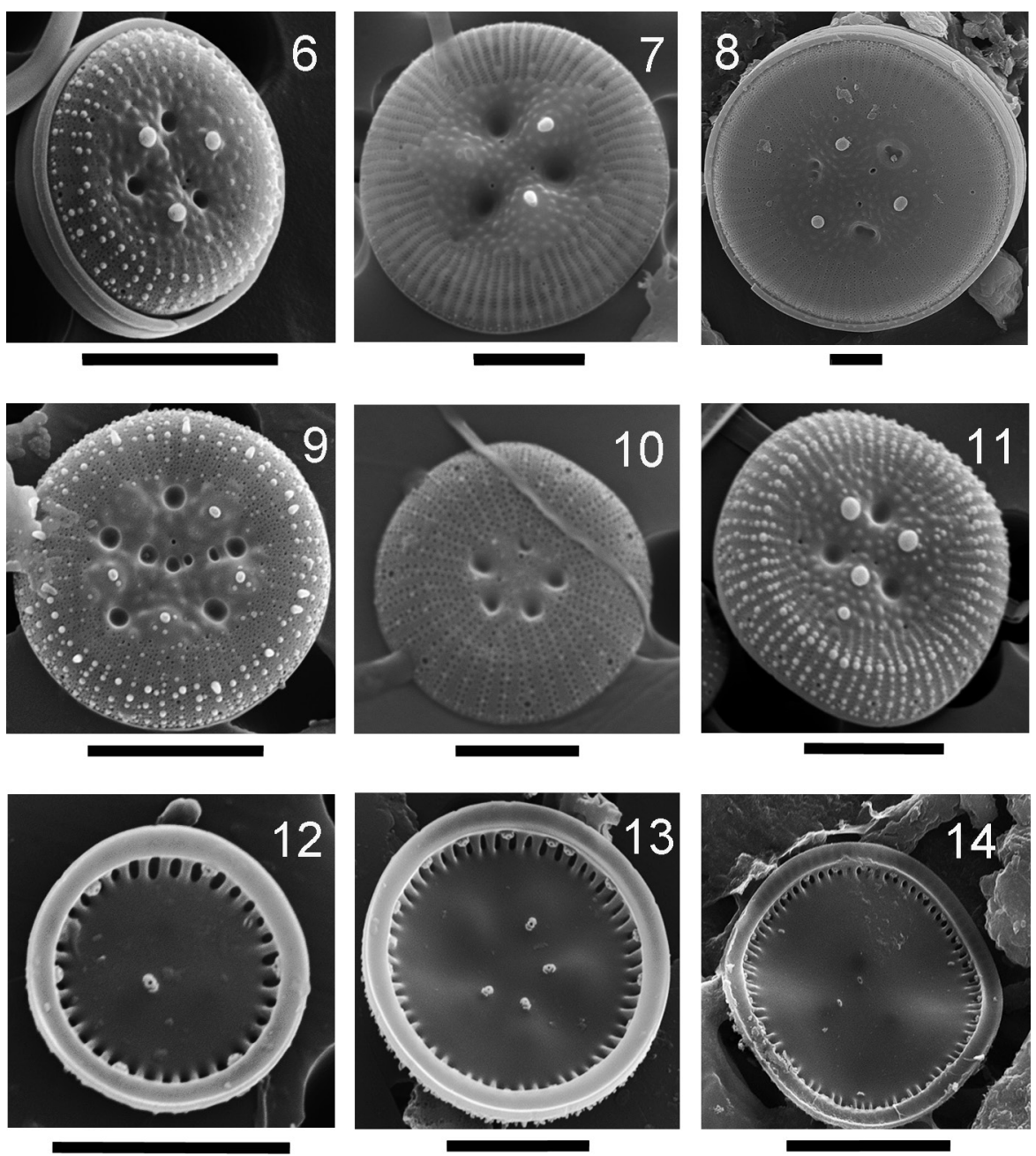

Figs 6-14. SEM micrographs of Pantocsekiella ocellata: (6-11) external view; (12-14) internal view; (6) valve with three OD and three papillae, interstriae ornamented with granules (from Lake Balaton); (7) valve with three OD and two papillae (from Lake Himód); (8) valve with three OD (twin OD-s) and three papillae (from Lake Visovac); (9) valve with seven OD and three papillae, interstriae ornamented with granules (from Lake Balaton); (10) valve with four OD without papillae (from Lake Dunaharaszti); (11) slightly quadrangular valve with three OD and three papillae, interstriae ornamented with granules (from Lake Visovac); (12) valve with one valve face fultoportula, costae are equal in length (from Lake Balaton); (13) valve with four valve face fultoportulae, costae bearing marginal fultoportulae are shorter (from Lake Balaton); (14) slightly quadrangular valve with two valve face fultoportulae and three rimoportulae, costae bearing marginal fultoportulae are shorter (from Lake Visovac). Scale bars (14) $10 \mu \mathrm{m}$; $(6,7,9,11-13) 5 \mu \mathrm{m}$; (10) $2.5 \mu \mathrm{m}$; (8) $2 \mu \mathrm{m}$. 
Pantocsekiella costei (Druart et F. Straub) K.T. KIss et Ács, comb. nov.

Basionym: Cyclotella costei Druart et F. Straub 1988, Description de deux nouvelles Cyclotelles (Bacillariophyceae) de milieux alcalins et eutrophes: Cyclotella costei nov. sp. et Cyclotella wuethrichiana nov. sp. - Schweiz. Z. Hydrol. 50, p. 182-183, figs. 7-13.

Synonyms: Cyclotella comta var. unipunctata FrICKE in SCHMIDT 1990, pl. 224, figs. 5-12; C. operculata var. unipunctata HustedT 1922b, p. 235; C. distinguenda var. unipunctata (HUSTEDT) HÅKANsSON et J.R. CARTER 1990, p. 154; C. cyclopuncta HÁKANSSON et J.R. CARTER 1990, p. 155, figs. 6-8; C. operculata f. minuta Grunow in VAn Heurck 1882, pl. 93, fig. 24; Lindavia costei (Druart et F. Straub) NaKov et al. 2015, p. 255.

Type locality: Lake Paladru (archaeological site of Les Grands Roseaux), France.

Pantocsekiella cretica (J. John et Economou-AmiLLI) K.T. KIss et Ács, comb. nov.

Basionym: Cyclotella cretica J. John et Economou-Amilli 1990, Cyclotella cretica, a new species of diatom from the island of Crete, Greece. - Diatom Research 5, p. 44, figs. 1-23.

Synonym: Lindavia cretica (J. JoHn et EcONOMOU-Amilli) NaKov et al. 2015, p. 255.

Type locality: Lake Kournas, Island of Crete, Greece.

Pantocsekiella delicatula (HustedT) K.T. KISS et Ács, comb. nov.

Basionym: Cyclotella delicatula HustedT 1952, Neue und wenig bekannte Diatomeen. IV. - Botaniska Notiser 1952, p. 376, figs. 34-36.

Synonym: Lindavia delicatula (HusTeDT) NAKOv et al. 2015, p. 255.

Type locality: Small groundwater Lake Seebachlacke near Kienberg-Gaming, Austria.

Pantocsekiella elymaea (Economou-Amilli) K.T. Kiss et Ács, comb. nov.

Basionym: Cyclotella elymaea Economou-Amilli 1991, Cyclotella elymaea, a new fossil species from the neogene basin of KozaniAeani-Servia, Northern Greece. - Diatom Research 6, p. 224, figs. $1-27$.

Synonym: Lindavia elymea (Economou-Amilli) NaKov et al. 2015, p. 255 .

Type locality: In fossil Neogene sediment of the Kozani-Aeani-Servia basin, Greece.

Pantocsekiella gordonensis (H.J. KLING et Håkansson) K.T. Kiss et Ács, comb. nov.

Basionym: Cyclotella gordonensis H.J. KLING et HÅKAnsson 1988 , A light and electron microscope study of Cyclotella species (Bacillariophyceae) from central and northern Canadian lakes. - Diatom Research 3, p. 70, figs. 51-52, 98-100.

Type locality:-_Lake Gordon, Canada.

Pantocsekiella gracilis (NiKITEEva et LiKHOSHWAY) K.T. Kiss et Ács, comb. nov.

Basionym: Cyclotella gracilis Nikiteeva et Likhoshway 1994, Cyclotella gracilis sp. nov. from Pleistocene material of Lake Baikal, Russia. - Diatom Research 9, p. 350, figs. 2-9.

Synonym: Lindavia gracilis (NIKITEEVA et LikHoshwAY) NAKOV et al. 2015 , p. 255
Type locality: Underwater Academic Ridge of Lake Baikal (56 $\left.26^{\prime} \mathrm{ON}, 107^{\circ} 44^{\prime} \mathrm{SE}\right)$, Russia.

Pantocsekiella granulata (Kulumbaeva et Genkal in Genkal \& Kulumbaeva) K.T. Kiss, Genkal et Ács, comb. nov.

Basionym: Cyclotella granulata Kulumbaeva et GenKal in GenKal \& Kulumbaeva 1990, About diatom algae (Centrophyceae) of Song-Köl Lake (Western Tian Shan). - Biologiia Vnutrennikh Vod (Biology of Inland Waters), Informatsii Biulleten 86, p. 23, pl. 1, figs. 12-14, pl. 2, figs. 1-6 (in Russian).

Type locality: Song-Köl Lake, Kyrgyzstan (USSR, lacus Sonkulj).

Pantocsekiella hinziae (Houk, C. KöNIG et KLEE) K.T. KISs, Ector et Ács, comb. nov.

Basionym: Cyclotella hinziae Houk, C. KöNIG et KLEE 2015, Cyclotella hinziae sp. nov. - a small Cyclotella (Bacillariophyceae) from subalpine lake Schliersee (Bavaria, Germany). - Fottea 15, p. 236, figs. 1-6, 19-37.

Type locality: Lake Schliersee, Germany.

Pantocsekiella hispanica (K.T. KISS, E. Hegewald et Ács) K.T. KIss et Ács, comb. nov.

Basionym: Cyclotella hispanica K.T. KISS, E. Hegewald et Ács 2002, Cyclotella hispanica a new dimorphic centric diatom species (Bacillariophyceae). - Algological Studies 106, p. 8, figs. 1-8, $10-18,20,23-47$.

Type locality: Lake Banyoles, Spain.

Pantocsekiella horstii (GenKAL et KulikovSKIY) K.T. Kiss, Genkal et Ács, comb. nov.

Basionym: Cyclotella horstii GenKaL et KuLIKovskiY 2012, Cyclotella horstii sp. nov. (Bacillariophyta) from Ivankovskoe reservoir (Volga reservoirs, Russia). - Phytotaxa 59, p. 56, figs. 2-34. Synonym: Lindavia horstii (GenKal et KuliKovskiY) NaKov et al. 2015, p. 255.

Type locality: Ivankovskoe Reservoir (Volga Reservoirs Series), Russia.

Pantocsekiella indistincta (BenetT et KocioleK in Kociolek et al.) K.T. Kiss, Ector et Ács, comb. nov. Basionym: Cyclotella indistincta BenETT et KocioleK in Kociolek et al. 2014, Diatoms of the United States 1: Taxonomy, ultrastructure and description of new species and other rarely reported taxa from lake sediments in the Western U.S.A. - Bibliotheca Diatomologica 61, p. 14, pl. 10, figs. 10-16, pl. 13, figs. 1-5.

Type locality: Huntington North Reservoir, Utah, $39^{\circ} 20^{\prime} 53.5^{\prime \prime} \mathrm{N}, 110^{\circ} 56^{\prime} 51.9^{\prime \prime} \mathrm{W}$, USA.

Pantocsekiella iranica (NeJADSATtARI et al. in KHEIRI et al.) K.T. KISs, Ector et Ács, comb. nov.

Basionym: Cyclotella iranica NejAdSATTARI et al. in Kheiri et al. 2013, Cyclotella iranica sp. nov. (Bacillariophyta: Coscinodiscophyceae), a new diatom from the Karaj River, Iran. - Phytotaxa 104 , p. 37 , figs. $2-14$

Synonym: Lindavia iranica (NejAdsatTARI et al. in KheIRI et al.) NAKov et al. 2015, p. 256. 
Type locality: Albourz, Karaj, Karaj River (epipelon), downstream of the Amir Kabir Dam, near the village of Aderan, elevation $1555 \mathrm{~m}, 35^{\circ} 53^{\prime} \mathrm{N}, 51^{\circ} 4^{\prime} \mathrm{E}$, Iran.

\section{Pantocsekiella kuetzingiana (THWAITES) K.T. KISS et} Ács, comb. nov.

Basionym: Cyclotella kuetzingiana THWAITES 1848, Further observations on the Diatomaceae with descriptions of new genera and species. - Ann. Magaz. Nat. Hist., 2nd series, 1, p. 169, pl. 11/D, figs. 1-5.

Synonym: Cyclotella krammeri HÅKANSSON 1990b, p. 263, figs. 3-10, 35-41.

Type locality:-Krageholmssjön, Sweden.

\section{Pantocsekiella melnikiae (GeNKAL et BondarenKo)} K.T. Kiss, GenKal et Ács, comb. nov.

Basionym: Cyclotella melnikiae GENKAL et BondARENKo 2010, Diatom algae in mountain lakes of the Dzherginskiy reserve (the Baikal area). 1. Centrophyceae. - Diatom Research 25, p. 283, figs. 2-19. Synonym: Lindavia melnikiae (GENKAL et Bondarenko) NAKOv et al. 2015 , p. 256.
Type locality: Lake Amut (north-eastern region of Lake Baikal), East Siberia, Russia.

Pantocsekiella minuscula (JuRILJ) K.T. KISS et Ács, comb. nov. et stat. nov.

Basionym: Cyclotella thienemannii var. minuscula JuRiLJ 1954, Flora i vegetacija Dijatomeja Ohridskog Jezera (Flora and vegetation of diatoms from Ochrida Lake in Yugoslavia). - Jugoslavenska Akademija Znanosti i Umjetnosti, Zagreb (Prirodoslovnih istraživanja) 26, p. 112, fig. $6 \mathrm{~d}$

Synonyms: Cyclotella minuscula (JuRILJ) CvetKoska in CvetKoskA et al. 2014, p. 328, figs. 65-99; Lindavia minuscula (JurILJ) NAKOV et al. 2015 , p. 256.

Type locality:- Lake Ohrid, Republic of Macedonia.

Pantocsekiella narochanica (Genkal et Mikheeva) K.T. Kiss, Genkal et Ács, comb. nov.

Basionym: Cyclotella narochanica GenKal et MiKheEva 2006, New for science species from the genus Cyclotella Kützing (Bacillariophyta). - International Journal of Algae 8, p. 77, pl. 1, figs. 1-6, pl. 2, figs. 1-6.

Table 5. The variability of morphological elements of Cyclotella ocellata, (Diam) valve diameter in $\mu \mathrm{m}$; (Striae) number of striae in 10 $\mu \mathrm{m}$; (vfp) number of valve face fultoportulae; (sp-vfp) number of satellite pores of valve face fultoportulae; (mfp) arrangement of marginal fultoportulae; (sp-mfp) number of satellite pores of marginal fultoportulae; (rp) number of rimoportulae; $\left(^{*}\right)$ according to measurements by microphotographs.

\begin{tabular}{|c|c|c|c|c|c|c|c|}
\hline Diam & Striae & vfp & sp-vfp & $\operatorname{mfp}$ & $\begin{array}{l}\text { sp- } \\
\text { mfp }\end{array}$ & $\mathbf{r p}$ & References \\
\hline $6-25$ & $13-15$ & & & & & & KRAMMER \& LANGE-Bertalot 1991 \\
\hline $3-33$ & $10-20$ & $1-3$ & 2 & on every $4-9$ costae & 2 & $1-3$ & KozURENKo et al. 1992 \\
\hline $5-27$ & $14-23$ & $1-6$ & 2 & on every $2-7$ costae & 2 & & Kiss et al. 1996 \\
\hline $5.6-25$ & $14-20$ & $0-5$ & 2 & on every $2-7$ costae & 2 & 1 & Kiss et al. 1999 \\
\hline $8-13$ & $15-18$ & $1-2$ & 2 & on every $2-4$ costae & 2 & 1 & Alfinito et al. 2001 \\
\hline $2-18$ & & $1-3$ & 2 & $\begin{array}{l}\text { on every }(4) 5-7 \\
\text { costae }\end{array}$ & 2 & 1 & HÅKANSSON 2002 \\
\hline $2.5-43$ & $10-19$ & $1-7$ & 2 & on every $2-6$ costae & 2 & $1-4$ & EDLUND et al. 2003 \\
\hline $5.5-35.3$ & $10-22$ & $1-6$ & & & & & GENKAL \& BondARENKo 2004 \\
\hline $3.4-44.2$ & $11-25$ & $1-13$ & $1-3$ & on every $1-8$ costae & 2 & $1-4$ & Genkal \& Popovskaya 2008a \\
\hline $4.4-16.4$ & $18-20$ & & & & & & Genkal \& Popovskaya 2008b \\
\hline $7.6-16.4$ & $14-20$ & & & & & & Popovskaya \& GenKal 2008 \\
\hline $3.5-24.3$ & $12-30$ & & & & & & GENKAL et al. 2009 \\
\hline $5-22$ & $14-20$ & $\begin{array}{l}1-4 \\
(5)\end{array}$ & 2 & on every $2-5$ costae & 2 & 1 & Houk et al. 2010 \\
\hline $5.3-17.8$ & $14-25$ & $1-9$ & $2 *$ & $\begin{array}{l}\text { on every } 4-6 \text { cos- } \\
\text { tae * }\end{array}$ & $2 *$ & $1 *$ & GENKAL \& YARUSHINA 2010 \\
\hline $6-18.6$ & $14-25$ & & & & & & KhaRitonov \& GenKal 2010 \\
\hline $8.8-22.2$ & $12-14$ & & & & & & GENKAL \& BondARENKo 2011 \\
\hline $4-44$ & $14-20$ & $1-13$ & 2 & on every $3-6$ costae & 2 & $1(2)$ & Kiss et al. 2012 \\
\hline $5.5-19$ & $19-22$ & & & & & & SOLAK \& KuLIKOVSKIY 2013 \\
\hline $5-19$ & $16-18$ & 1 & 2 & on every $4-5$ costae & 2 & 1 & CvetKoska et al. 2014 \\
\hline $2-44.2$ & $10-30$ & $0-13$ & $1-3$ & on every $1-9$ costae & 2 & $1-4$ & $\min -\max$ from the table \\
\hline
\end{tabular}


Synonym: Lindavia narochanica (GENKAL et MiKhEEVA) NAKOv et al. 2015 , p. 256.

Type locality: Lake Naroch, Belarus.

Pantocsekiella notata (LoSEva) K.T. KISS et Ács, comb. nov.

Basionym: Cyclotella notata Loseva 1980, Some new data on the frustule structure of two representatives of the genus Cyclotella from Upper Pliocene deposits in Kama River. - Botanicheskii Zhurnal 65, p. 1620-1621, pl. 2, figs. 1-23.

Synonym: Lindavia notata (Loseva) NAKov et al. 2015, p. 256.

Type locality: Kama River basin (Upper Pliocene deposits), Omara, Republic of Tatarstan, Russia.

Pantocsekiella paleo-ocellata (VOSSEL et VAN DE VIJVER) K.T. Kiss, Ector et Ács, comb. nov.

Basionym: Cyclotella paleo-ocellata Vossel et al. 2015, Cyclotella paleo-ocellata, a new centric diatom (Bacillariophyta) from Lake Kinneret (Israel). - Fottea 15, p. 65, figs. 2-18, 20-34.

Synonym: Lindavia paleo-ocellata (Vossel et al.) NAKov et al. 2015 , p. 257

Type locality: Lake Kinneret, Israel.

Pantocsekiella palustris (GENKAL et KULIKOVSKIY) K.T. Kiss, GenKal et Ács, comb. nov.

Basionym: Cyclotella palustris GenKal et KuliKovsKIY 2008, New centric diatom species (Bacillariophyta) from the Polistovo-Lowatsky sphagnous tract (Rdeisk State Nature Reserve). - Botanicheskii Zhurnal 89, p. 773, pl. 2, figs. 1-10.

Synonym: Lindavia palustris (GenKal et KulikovskiY) Nakov et al. 2015 , p. 257

Type locality: Swamp Rdeiskiy, region Novgorod, Russia.

Pantocsekiella paraocellata (CVETKOSKA et al.) K.T. Kiss et Ács, comb. nov.

Basionym: Cyclotella paraocellata CveTKoska et al. 2014, Observations of the genus Cyclotella (Kützing) Brébisson in ancient lakes Ohrid and Prespa and a description of two new species $C$. paraocellata sp. nov. and $C$. prespanensis sp. nov. - Nova Hedwigia 98, p. 317, figs. 1-23, 30-45

Synonym: Lindavia paraocellata (CvetKoska et al.) NAKov et al. 2015 , p. 257.

Type locality: Lake Prespa, near village Krani, N 4056'06", E 2104'27", Republic of Macedonia.

Pantocsekiella polymorpha (B. MEYER et HÅKAnsSON) K.T. KIss et Ács, comb. nov.

Basionym: Cyclotella polymorpha B. MeYer et HÁKAnsson 1996, Morphological variation of Cyclotella polymorpha sp. nov. (Bacillariophyceae). - Phycologia 35, p. 64, figs. 1-29.

Synonym: Lindavia polymorpha (B. MeYER et HÅKANSSON) NAKOV et al. 2015, p. 257.

Type locality: Lake Kinneret, Israel.

Pantocsekiella prespanensis (CVETKOSKA et al.) K.T. Kiss et Ács, comb. nov.
Basionym: Cyclotella prespanensis CVETKOSKA et al. 2014, Observations of the genus Cyclotella (Kützing) Brébisson in ancient lakes Ohrid and Prespa and a description of two new species C. paraocellata sp. nov. and C. prespanensis sp. nov. - Nova Hedwigia 98, p. 323, figs. 52-64.

Synonym: Lindavia prespanensis (CVETKOSKA et al.) NAKOv et al. 2015, p. 257.

Type locality: Lake Prespa, near village Stenje, N 4056'40"; E 2054'15", Republic of Macedonia.

Pantocsekiella pseudocomensis (SCHEFFLER) K.T. KIss et Ács, comb. nov.

Basionym: Cyclotella pseudocomensis SCHEFFLER 1994, Cyclotella pseudocomensis nov. sp. (Bacillariophyceae) aus norddeutschen seen. - Diatom Research 9, p. 356, figs. 1-31.

Synonym: Lindavia pseudocomensis (SCHEFfler) NAKov et al. 2015, p. 257.

Type locality: Großer Boberowsee, near Neuglobsow, Brandenburg, Germany.

Pantocsekiella reczickiae (KHURSEvich et Loginova) K.T. KIss et Ács, comb. nov.

Basionym: Cyclotella reczickiae Khursevich et Loginova 1984, A new species of the genus Cyclotella (KÜTz.) BRÉB. from the Lower Anthropogene ancient lacustrine deposits of Belarus and Latvia. Doklady Akademii nauk BSSR 28, p. 52, pl. 1, figs. 1-7, pl. 2, figs. $1-4$.

Synonym: Lindavia reczickiae (KHURSEvich et LogINOVA) NAKOv et al. 2015 , p. 257.

Type locality:- Republic of Belarus and Latvia (Lower Pleistocene deposits).

Pantocsekiella reczickiae var. diversa (LogINOvA) K.T. Kiss et Ács, comb. nov.

Basionym: Cyclotella reczickiae var. diversa Loginova 1989, Two new taxa of the genus Cyclotella (Bacillariophyta). - Botanicheskii Zhurnal 74, p. 1781-1782, pl. 2, figs. 3-5, 8-12.

Synonym: Lindavia reczickiae var. diversa (LogINOvA) NAKOv et al. 2015 , p. 258

Type locality:-Krasnaya Dubrova, Rechitsa district, Byelorussian SSR.

Pantocsekiella rossii (Håkansson) K.T. KIss et Ács, comb. nov.

Basionym: Cyclotella rossii H̊̊KANSSON 1990b: A comparison of Cyclotella krammeri sp. nov. and C. schumannii Håkansson stat. nov. with similar species. - Diatom Research 5, p. 266-267, figs. 18-27, 46-49.

Synonym: Lindavia rossii (HÅKANSSON) NAKOV et al. 2015, p. 258.

Type locality:-Laxå, Sweden.

Pantocsekiella schumannii (GRUNOW in SCHNEIDER) K.T. KIss et Ács, comb. nov.

Basionym: Cyclotella kuetzingiana var. schumannii GRUNow in SCHNEIDER 1878, Naturwissenschaftliche Beiträge zur Kenntniss der Kaukasuländer, auf Grund seiner Sammelbeute herausgegeben von Dr. Oscar Schneider. Dresden. Im Verlage der Burdach'schen Hofbuchhandlung. Veröffentlicht von der naturw. Gesellschaft ,Isis' zu Dresden, p. 127. Illustrated by Grunow in Van Heurck (1882): 
Synopsis des Diatomées de Belgique. Atlas. Ducaju et Cie., Anvers, pl. 94, figs. 2-3.

Synonyms: Cyclotella schumannii (GRUNOw) HÅKANSSON 1990b, p. 267, figs. 28-31; Lindavia schumannii (Grunow) NAKov et al. 2015, p. 258.

Type locality: Domblitten (diatomaceous earth - Kieselguhr von Domblitten), near Zinten (East Prussia), now Kornevo (Russia).

\section{Pantocsekiella strelnikovae (GENKAL et YARISHINA)} K.T. KIss, GenKal et Ács, comb. nov.

Basionym: Cyclotella strelnikovae GenKaL et YARUSHINA 2004, New species of the genus Cyclotella (Bacillariophyta) from the polar Ural Lakes. - Botanicheskii Zhurnal 89, p. 1498, pl. 1, figs. 1-6, pl. 2, figs. 1-6, pl. 3, figs. 1-6, pl. 4, figs. 1-9.

Synonym: Lindavia strelnikovae (GenKal et Yarushina) NaKov et al. 2015, p. 258.

Type locality:-_Lake Upper Ingilor (Polar Ural), Russia.

Pantocsekiella trichonidea (Economou-Amilli) K.T. Kiss et Ács, comb. nov.

Basionym: Cyclotella trichonidea Economou-Amilli 1979, Two new taxa of Cyclotella Kützing from Lake Trichonis, Greece.- Nova Hedwigia 31 , p. 468 , figs. 1-20.

Synonym: Lindavia trichonidea (EсоNomou-Amildi) NaKov et al. 2015, p. 259.

Type locality: Lake Trichonis, Greece.

\section{Pantocsekiella tripartita (HÅKANSSON) K.T. KISS et} Ács, comb. nov.

Basionym: Cyclotella tripartita HÅKANsson 1990a, Cyclotella tripartita nov. sp. (Bacillariophyceae) and the relationship to similar taxa. - In: Ricard, M. (ed.): Ouvrage dédié à la Mémoire du Professeur Henry Germain. - p. 78, pl. 1, figs. 1-4.

Synonyms: Cyclotella comensis sensu MANGUIN 1961, p. 268, pl. 1 (26), figs. 3, 4, pl. 5 (31), fig. 4; C. kisselevii Ковоткеvich 1959, p. 92, figs. 2-4; Lindavia tripartita (HǍkansson) NAKov et al. 2015, p. 259.

Type locality:-Desperation Lake $\left(68^{\circ} 20^{\prime} \mathrm{N}, 158^{\circ} 45^{\prime}\right.$ W), Alaska, USA.

\section{Pantocsekiella wuethrichiana (DrUART et F. STRAUB)} K.T. KIss et Ács, comb. nov.

Basionym: Cyclotella wuethrichiana Druart et F. Straub 1988, Description de deux nouvelles Cyclotelles (Bacillariophyceae) de milieux alcalins et eutrophes: Cyclotella costei nov. sp. et Cyclotella wuethrichiana nov. sp. - Schweiz. Z. Hydrol. 50, p. 186, figs. 1, 2, $4,6,14,16$

Synonym: Lindavia wuethrichiana (Druart et F. Straub) Nakov et al. 2015 , p. 259.

Type locality: Lake Le Loclat, near Neuchâtel, Switzerland.

\section{Discussion}

For the supplementary description of the type species of the genus Pantocsekiella, we relied pronouncedly on the findings of the studies in the recent decades beside our previous researches. These investigations presented the detailed electron microscope analyses of Cyclotella ocellata (the most important investigations are: Lowe 1975; GenKal \& Kuzmin 1979; GenKal \& Zagorenko 1987; KleE \& Steinberg 1987; HÅkansSON 1990b; Hegewald \& HindáKová 1997; KNIE \& HÜBEnER 2007; Cherepanova et al. 2010 and the references listed in the Table 5) showing the morphological features of the species, and proving the remarkable variability and heterovalvate character of the valve face structure. It is notable that specimens of the genus Pantocsekiella having small diameter resemble to each other from outside (e.g. Cyclotella ocellata: GENKAL \& Zagorenko 1987, figs. p-s; C. hispanica: Kiss et al. 2002, figs. 7, 8; C. comensis: ScheFfler \& Morabito 2003, figs. 18-20, 24).

When the former Centrales order was divided into two clades (Mediophyceae and Coscisnodiscophyceae) based on molecular, cytological and morphological results, rimoportula and marginal fultoportula were important morphological features (MEDLIN \& KA-
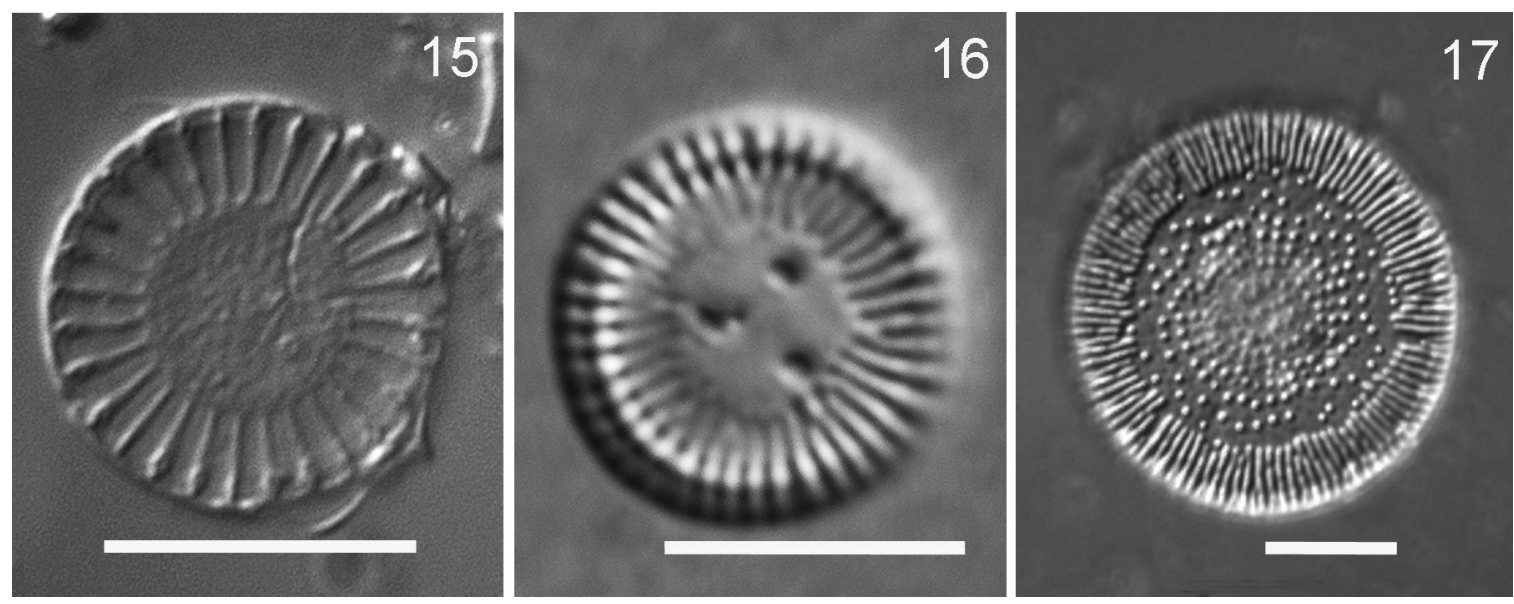

Figs 15-17. LM micrographs of characteristic species for Cyclotella (C. meneghiniana), Pantocsekiella (P. ocellata) and Lindavia (L. radiosa) genera. Scale bars (15) $10 \mu \mathrm{m} ;(16,17) 5 \mu \mathrm{m}$. 
CZMARSKA 2004), and therefore their differences should be correlated to the phylogenetic divergences.

Shape and position of rimoportula is characteristic to the Cyclotella meneghiniana group [including C. atomus Hustedt (1937: 143), C. cryptica Reimann et al. (1963: 82), C. choctawhatcheeana PRASAD in PRASAD et al. (1990: 419), C. distinguenda Hustedt (1927: 320), C. litoralis C.B. Lange et Syvertsen (1989: 343-344), C. quillensis L.W. BAILEy (1921: 159), C. striata (KütZING) GRUNOw in Cleve et GRUNOw (1880: 119), see Fig. 5. in phylogenetic tree]; it is situated on the edge arising from the valve mantle costa internally. Marginal fultoportulae can be found also on costae that are identical. Previously Cyclotella involved the Discostella species that were later separated as a distinct genus based on both morphological (HouK \& KLEE 2004) and phylogenetic evidences (JuNG et al. 2010). The rimoportula of Discostella can be found also on the edge, on the costae, however, the marginal fultoportulae are situated between costae. The rimoportulae are usually sessile, rarely petiolate.

NAKOV et al. (2015) identified the rimoportula position as a synapomorphy for the Cyclotella comta and $C$. ocellata groups and they transferred all taxa showing this synapomorphy into the genus Lindavia. As they cited THERIOT et al. (1987b) "from a phylogenetic perspective, both areolae and fultoportulae on the valve face are problematic because both are plesiomorphic within Thalassiosirales", but the cited paper does not contain such statement. We consider that the areolae on the valve face with domed cribrum are apomorphic characters, not plesiomorphic, because they did not appear in the Pantocsekiella yet. Based on the phylogenetic tree of ALVERSON (2014) those groups having these features (e.g. Stephanodiscus, Cyclostephanos) diverged later than those ones lacking areolae on the valve face (e.g. Cyclotella sensu stricto).

In Handmannia genus which were also transferred to Lindavia by NAKOV et al. (2015) the areolae in the central area of valve face are covered by domed cribrum and there are several valve face fultoportulae on several species (e.g. H. comta (EhrenberG) Kociolek \& Khursevich in Khursevich \& Kociolek (2012: 339)), or there are only areolae (e.g. H. glabriuscula (GRUNow) Kociolek et Khursevich in Khursevich \& KociOLEK (2012: 339)). Comparing the two species under SEM shows that Pantocsekiella ocellata does not possess these important characteristics of the Handmannia (Puncticulata) genus. Species of the "Cyclotella ocellata group" can have more than one valve face fultoportulae, but nothing else penetrate the central area of the valve face. Kociolek \&Williams (2015) pointed out that "it would follow that all the taxa to be included in that group should have the diagnostic feature(s)" and draw attention to the importance of monophyly for describing new genera.
Several studies searched for a barcode that can be used for diatom species identification [e.g. the V4 region of 18S rDNA, ZiMMERMANN et al. (2011) and a region at the 3' end of $r b c \mathrm{~L}$, HAMSHER et al. (2011)]. For precise identification an appropriate threshold is needed. Some authors tried to determine a threshold at species level on certain markers (e.g. LUDDINGTON et al. 2012), but it proved to be difficult (RIMET et al. 2014).

Establishing a threshold at genus level is more difficult because "genera form wider taxonomic groups than species do and include different lineages" (KERMARREC et al. 2014). Examining reference libraries KermarRec et al. (2014) attempted to define inter-/intraspecies and inter-/intrageneric thresholds for assigning genus and species names to sequences from benthic communities. They tested the thresholds on mock community with known composition (mainly pennates). They obtained the best estimation of the real community composition using 99\% sequence identity threshold for $18 \mathrm{~S}$ rDNA at both levels, $99 \%$ species and $98 \%$ genus threshold for $r b c \mathrm{~L}$. The read selection criteria used for species was probably too strict for the assignment of genus names. Mean distance of Pantocsekiella group from all other genera studied was above $2 \%$ in the case of $r b c \mathrm{~L}$. This was true for pairwise distances. In the case of the long 18S rDNA the mean distance of Pantocsekiella from Cyclostephanos and Stephanodiscus was under $1 \%(0.89 \%$ and $0.85 \%$, respectively). Pairwise distances of Pantocsekiella with most of Stephanodiscus and Cyclostephanos sequences as well as Praestephanos triporus were below 1\% (0.56$0.84 \%$ in all sequences, $0.54-0.94 \%$ ). It should be considered that KERMARREC et al. (2014) defined thresholds mostly based on pennates. According to KeRMARREC et al. (2014), identity threshold applicable to all diatom taxa is difficult to establish because diatom lineages have not all evolved at the same rate. Investigating the $333 \mathrm{nt}$ of $18 \mathrm{~S}$ rDNA including V4 region of 26 genera in orders Thalassiosirales, Lithodesmiales and Cymatosirales LuDDINGTON et al. (2012) found intergeneric p-distance ranged from $0.001-0.235(0.1-23.5 \%)$. In the analysis of all $18 \mathrm{~S}$ rDNA sequences the mean distance of Pantocsekiella from Lindavia (Handmannia) ( $1.76 \%$ in the $360 \mathrm{nt}$ region) the sister group of Pantocsekiella (Fig. 5) fit into this range, but it was under the $2 \%$ threshold that LuDDINGTON et al. (2012) set for species identification. Comparing of Cyclotella comensis group to Cyclostephanos delicatus (GENKAL) CASPER \& SchefFler (1990: 311) and Stephanodiscus alpinus Hustedt (1942: 412) based on similar region of $18 \mathrm{~S}$ rDNA KisTENiCH et al. (2014) also found intergeneric distance lower than 2\% (0.74\%). The PantocsekiellaStephanodiscus and Pantocsekiella-Cyclostephanos distance in our analysis with more sequences from both genera ( $1.10 \%$ and $1.25 \%$, respectively) exceeded this value but remained under $2 \%$.

In partial region $(507 \mathrm{nt})$ of $r b c \mathrm{~L}$ KISTENICH et al. (2014) detected 4.54-6.11\% intergeneric distance. 
Although in the analisys of all $r b c \mathrm{~L}$ sequences, Lindavia (Handmannia) - Pantocsekiella distance (4.30\%) remained below this range, Pantocsekiella - Stephanodiscus distance $(4.95 \%)$ fell into it and Pantocsekiella - Cyclostephanos distance (6.36\%) exceeded it. It should be noted that Pantocsekiella sequence from Lake Himód was shifted with 105 nt in 3' direction comparing to those of KISTENICH et al. (2014), therefore the comparison was possible on the overlapping 402 nt region.

KI (2009) and JUNG et al. (2010) investigated the relationship of the genera Cyclotella, Discostella and Stephanodiscus using almost full-length of $18 \mathrm{~S}$ rDNA (1689 and 1704 sites, respectively). The results of their $\mathrm{p}$-distance and phylogenetic analyses showed the significant separation of the three genera. However, these studies extended to only the $C$. meneghiniana group within the Cyclotella genus. They excluded $C$. ocellata and $C$. bodanica because they considered these species as belonging to Discostella or a new genus (Jung et al. 2010). The corrected $\mathrm{p}$-distance calculated using Kimura two-parameter model was $5,4 \pm 0,45$ between Stephanodiscus and Cyclotella, 1,7 $\pm 0,28$ between Stephanodiscus and Discostella (KI 2009), the similarity between Discostella and Cyclotella was $94.4 \pm 0.5 \%$ (JuNG et al. 2010). The mean distance calculated with the same model on the long region (1564 nt) of $18 \mathrm{~S}$ rDNA between Cyclotella and Discostella was 4.89\%; between Cyclotella and Stephanodiscus it was $4.69 \%$ and between Discostella and Stephanodiscus $1.60 \%$. The Pantocsekiella-Lindavia (Handmannia) distance with this method was $1.15 \%$.

One Stephanodiscus strain investigated by $\mathrm{K}_{\mathrm{I}}$ (2009) has been recently transferred into the new genus Praestephanos, as P. triporus (TuJ et al. 2014). This genus was described based on morphological characters (position of rimoportulae and marginal fultoportulae, pattern of areolae) and its unique position on phylogenetic tree based on four markers (SSU and LSU rDNA, $r b c \mathrm{~L}$ and $p s b \mathrm{C})$. Praestephanos triporus showed $0.56-1.12 \%$ pairwise $\mathrm{p}$-distance in the short and $0.96-1.12 \%$ distance in the long region of $18 \mathrm{~S}$ rDNA and $3.86-4.59 \%$ pairwise $\mathrm{p}-$ distance in the short and $3.00-3.67 \%$ distance in the long region of $r b c \mathrm{~L}$ from the members of Pantocsekiella.

The topology of both maximum likelihood and Bayesian inferred phylogenetic trees differed from previously published Thalassiosirales trees (ALVERSON et al. 2007, Alverson 2014). A main difference was the lack of monophyly of Stephanodiscus and within it $C y$ clostephanos species in the $18 \mathrm{~S}$ rDNA tree suggesting that two genera cannot be distinguished by the studied region that may have not enough phylogenetic signal in this group of diatoms. The mean distance between these groups was low in the studied region $(0.33)$ that was compared among all used sequences. This region that contained V4 subregion was found to show very low variation within the Stephanodiscus (ZIMMERManN et al. 2011). The distance was also low in the long stretch (0.27). Most of the differences occurred only in one sequence. Comparing just Cyclostephanos and Stephanodiscus sequences six parsimony informative sites were found with MEGA software (at parsimony informative sites at least two different nucleotides occur each of them in at least two taxa). At these sites the substitutions were characteristic only to a group of sequences but none of the differences separated the two genera (e.g. at $188^{\text {th }}$ position all Cyclostephanos, but C. tholiformis had guanine, Stephanodiscus sequences and $C$. tholiformis contained adenine; at $239^{\text {th }}$ position all Cyclostephanos but along with $S$. hantzschii WTC21 contained cytosine instead of timine). Based on the phylogenetic tree of Alverson (2014) Stephanodiscus and Cyclostephanos are closely related, relatively recently diverged genera that may explain the low intergeneric variation. In ALverson et al. (2007) the monophyly of Cyclostephanos and Stephanodiscus was proved based on combined dataset of $18 \mathrm{~S}$ and $28 \mathrm{~S}$ rDNA. The 18S rDNA alone may not be suitable for separating these genera, just in combination with another gene e.g. 28S rDNA or as in our case with $r b c \mathrm{~L}$. Differences at four sites in the extended sequenced region of 18S rDNA separated Lindavia (Handmanna) from Pantocsekiella.

In the case of $r b c \mathrm{~L}$ the monophyly of Stephanodiscus was confused by Praestephanos triporus grouping with Stephanodiscus sequences. This genus was established from species that drifted from Stephanodiscus (Tuj et al. 2014). The sequence used was also originally identified as Stephanodiscus.

Based on all above mentioned results, not only morphological but also molecular investigations clarified that the former Cyclotella genus was needed to be divided into several new genera, as did NAKOV et al. (2015). Cyclotella ocellata and C. bodanica represented lineages separate from the $C$. meneghiniana group (Alverson et al. 2007). Previously the sequences of only two species Cyclotella (Lindavia) ocellata and Cyclotella (Puncticulata/Handmannia/Lindavia) bodanica were available beside the Cyclotella meneghiniana group. To investigate if $C$. ocellata belonged to the genus Lindavia we supplemented previous data with sequences of additional species (Cyclotella comensis group and Handmannia radiosa). Our results indicated that Cyclotella ocellata did not belong to either Puncticulata (Handmannia/Lindavia) or Cyclotella or other established genera (because of the high genetic distance). Therefore we propose the drift of the species into a new genus, Pantocsekiella as its generitype species.

\section{Differential diagnosis of the three genera (Figs 15-25)}

Cyclotella: striae are of equal length, central area round (Figs 15, 18); alveolae simple (Fig. 19); a single rimoportula (rarely two) arising near the margin from 

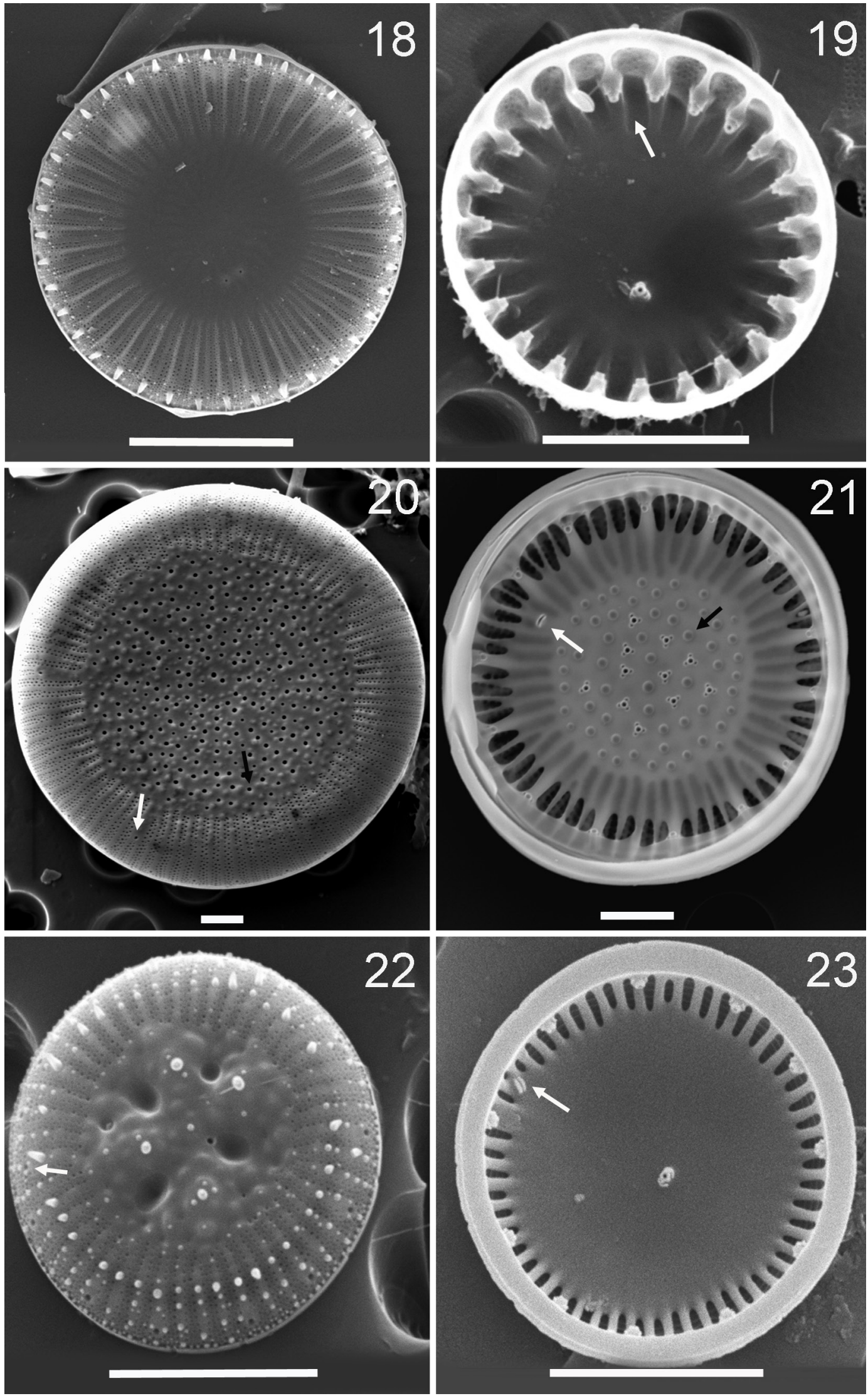

Figs 18-23. SEM micrographs of characteristic species for Cyclotella, Lindavia (Handmannia) and Pantocsekiella genera (outside and inside view): $(18,19)$ C. meneghiniana, white arrow: rimoportula; $(20,21)$ L. radiosa, white arrow: rimoportula; black arrow: domed cribra on inside view and foramina on outside view; $(22,23) P$. ocellata, white arrow: rimoportula. Scale bars $(18) 10 \mu \mathrm{m} ;(19,22,23) 5 \mu \mathrm{m} ;(20,21) 2 \mu \mathrm{m}$. 
the valve mantle costa internally (Fig. 19) and opening by distinct round aperture or slit externally.

Lindavia (Handmannia): striae of unequal length (Figs 17, 20, 21), central area polygonal; presence of valve face fultoportulae and areolae or only areolae; areolae with internal domed cribra and external foramina (Figs 20, 21); presence of a complex alveolar structure composed primary thick costae internally bearing marginal fultoportulae, secondary thin costae which can be forked (Fig. 21); sessile rimoportula on the valve face in the submarginal zone (Figs 20, 21).

Pantocsekiella: striae of unequal length (Figs 16, 22), central area polygonal; flat or radially or tangentially undulated; alveolae simple (Fig. 23); one or a few sessile rimoportulae are present in the submarginal zone of the valve face or at the end of the central lamina (Fig. 23). Internally no any structure (except VFP) penetrates the central part of cell wall.

In the literature uncertainty can be observed about the characterisation of "Puncticulata comta", the "Puncticulata" genus and the "Cyclotella ocellata" group, their coherency or separation. LowE (1975) rated the Cyclotella genus into three groups $(C$. meneghiniana group, $C$. comta group and $C$. stelligera group). Within the C. comta group ("...the comta group, includes C. comta, C. antiqua, C. ocellata and C. michiganiana") "Cyclotella comta and $C$. antiqua are very closely related and may constitute a subgroup of the comta group." This means that he did not consider $C$. ocellata to belong to the comta subgroup.

HÅKANSSON (2002) mentioned the following as the important characteristic of the genus Puncticulata: "Central area ... with both areolae and fultoportulae or areolae only or fultoportulae only." The latter feature (fultoportulae only) can be observed on two species: $P$. notata (Loseva) HÅkansson (2002: 126) and $P$. kurdica (HÅKANSSON) HÅKANSSON (2002: 129). Regarding to their morphological properties these two species significantly differ from the other species of the genus. On SEM photographs the external valve face is confusingly similar to the $C$. ocellata. On $P$. notata recordings (HÅKANSSON 2002: figs 475-478) 3-4 orbiculi depressi can be seen, on the internal side of the valve the structure of the alveolar chambers and costae actually resembles to that of the genus Puncticulata (HÅkansson 2002:figs 479-481), but GenKal \& PopOVSKAYA (2008a: figs. 26-32) found similar alveolar chamber/costa structure in C. ocellata. On $P$. kurdica recordings (HÅKANSSON 2002, figs 482-485) 4-6 orbiculi depressi can be seen; on the internal side of the valve the structure of the alveolar chambers and costae correspond with that of C. ocellata (HAKANSSON 2002, figs 487,488 ), and the many valve face fultoportulae are also characteristic to $C$. ocellata (GenKal \& PopOVSKAYA 2008a). For all these reasons, we consider that $P$. notata and $P$. kurdica could not be classified to the Puncticulata genus.

This opinion is supported by the fact that KHUR-
SEVICH \& KoCIOLEK (2012) wrote the following among the characteristics of the genus Handmannia: "... presence of both areolae and valve face fultoportulae, or areolae only within the central area". They did not rank either C. kurdica or C. notata to the genus Handmannia, the latter was rated into the $12^{\text {th }}$ Cyclotella group. NAKOv et al. (2015) synonymized those as Lindavia based on the nomenclatural priority.

Identification key - Distinctive light microscopic characters of the three genera
1. Striae of equal length ... Cyclotella
- Striae of unequal length ... 2
2. Central area with areolae ... Lindavia (Handmannia)
- Central area without areolae ... Pantocsekiella

Amended diagnosis of Lindavia genus is based on several works where Lindavia, Puncticulata, Handmannia were morphologically characterized (SснÜтT 1989a, b; De Toni \& Forti 1900; HANDMANN 1913; HÅKANSSON 2002; KHURSEVICH \& KocioleK 2012; NAKOV et al. 2015).

\section{Lindavia (F. SchÜtT) DE ToNI et FoRTI}

Basionym: Cyclotella socialis F. Schütт (1899a): Berichte der Deutschen Botanischen Gesellschaft 17: 220. Figures: Abbildungen der Jahrbücher für wissenschaftliche Botanik, pl. 7, figs. 23-35, pl. 8, figs. 37, 40. 1899.

Diagnosis: Frustules are disc-shaped, solitary, seldom in short chains. Valves circular or oval-elliptic or oblong-elliptic, with almost flat, concave or convex, or concentrically undulate, or tangentially undulate central area and a striated marginal zone. Central area slightly polygonal, with areolae and fultoportulae or only areolae. Loculate areolae (internally with domed cribra) form distinct radial rows, sometimes parallel rows or groups (without distinct order). Fultoportulae on the valve face with three satellite pores (rarely with two or four) are located in areolar rows, replacing oneseveral areolae in every row or sometimes in the slope of the central undulation. The marginal part of the valve is structured by long or short striae externally, separated by hyaline strips; striae are straight, more or less equal in length and a few of them are bifurcated. The striae of the marginal area are composed of small areolae, mostly increasing in numbers towards and onto the mantle. Complex alveolae are present within the marginal area internally. The inner aperture of the alveolae is elongated. Costae are usually equal in length but those bearing a fultoportula are often shorter and thick. There are secondary thin costae between thick ones, which can be forked-branched in some species. Fultoportulae situated on the mantle, externally with slightly thickened apertures on the slightly thicker interstriae, internally with two satellite pores. The valve has one or a few rimoportulae situated in the submarginal zone on 
the costa or just below it, or on the valve face (sessile internally and round or slit-like aperture externally); the orientation of the lip varies.

Type species: Lindavia socialis (F. SCHÜTT) DE TonI et FORTI (1900: 553).

\section{ACKNOWLEDGEMENTS}

The authors would like to thank Balázs Vajna for his help in phylogenetic analysis, to Anique Stecher and Bánk Beszteri for their help in the molecular study. This study was in part supported by Hungarian National Science Foundation (KTIA-OTKA 80140), Luxembourg Institute of Science and Technology (TAXODIA project) for Luc Ector and Russian Science Foundation (14-14-00555) for Sergei I. Genkal. The authors thank Pierre Compère for his help with nomenclature rules, Saúl Blanco and an anonymous reviewer for valuable comments and helpful suggestions to the manuscript.

\section{REFERENCES}

Alfinito, S.; Cavacini, P. \& Tagliaventi, N. (2001): The genus Cyclotella (Bacillariophyta, Thalassiosiraceae) in fresh- and brackish-water habitats of Latium and Molise (Central Italy). - Algological Studies 101: 57-73.

Altschul, S.F.; Gish, W.; Miller, W.; Myers, E.W. \& LipMAN, D.J. (1990): Basic local alignment search tool. - Journal of Molecular Biology 215: 403-410. http:// dx.doi.org/10.1016/S0022-2836(05)80360-2

Alverson, A.J. (2014): Timing marine-freshwater transitions in the diatom order Thalassiosirales. - Paleobiology 40: 91-101. http://dx.doi.org/10.1666/12055

Alverson, A.J.; Jansen, R.K \& Theriot, E.C. (2007): Bridging the Rubicon: Phylogenetic analysis reveals repeated colonizations of marine and fresh waters by thalassiosiroid diatoms. - Molecular Phylogenetics and Evolution 45: 193-210. http://dx.doi.org/10.1016/j.ympev.2007.03.024

BaILey, L.W. (1921): Diatoms from the Quill Lakes, Saskatchewan, and from Airdrie, Alberta. - Contributions to Canadian Biology 11: 157-165, pls 1-2.

BRÉBISSON, A. DE (1838): Considérations sur les Diatomées et essai d'une classification des genres et des espèces appartenant à cette famille. - 20 pp., Brée l'Ainé Imprimeur-Libraire, Falaise.

Brightwell, T. (1860): On some of the rarer or undescribed species of Diatomaceae. Part II. - Quarterly Journal of Microscopical Science, London 8: 93-96, 139, pls. V, VI.

CASPER, S.J. \& SCheffler, W. (1990): Cyclostephanos delicatus (Genkal) Casper et Scheffler comb. nov. from waters in the northern part of Germany. - Archiv für Protistenkunde 138: 304-312. http://dx.doi. org/10.1016/S0003-9365(11)80038-2

Cherepanova, M.V.; Usol'tseva, M.V.; PushKar, V.S. \& DuBROVINA, YU.F. (2010): Morphogenesis in Cyclotella ocellata-complex from Lake El'gygytgyn (Chukchi Peninsula) during the Pleistocene-Holocene. Paleontological Journal 44: 1252-1261. http:// dx.doi.org/10.1134/S0031030110100035

Cleve, P.T. \& Grunow, A. (1880): Beiträge zur Kenntniss der Arctischen Diatomeen. - Kongliga Svenska Vetenskaps-Akademiens Handlingar 17: 1-121, 7 pls.
Cvetkoska, A.; Hamilton, P.B.; Ognjanova-Rumenova, N. \& Levkov, Z. (2014): Observations of the genus $C y$ clotella (Kützing) Brébisson in ancient lakes Ohrid and Prespa and a description of two new species C. paraocellata sp. nov. and C. prespanensis sp. nov. - Nova Hedwigia 98: 313-340. http://dx.doi. org/10.1127/0029-5035/2014/0154

Daugbjerg, N. \& Andersen, R.A. (1997): A molecular phylogeny of the heterokont algae based on analyses of chloroplast-encoded $r b c \mathrm{~L}$ sequence data. - Journal of Phycology 33: 1031-1041. http://dx.doi.org/10.1111/ j.0022-3646.1997.01031.x

De Toni, G.B. \& Forti, A. (1900): Contributo alla conoscenza del plancton del Lago Vetter. - Atti del Reale Istituto Veneto di Scienze Lettero ed Arti 59: 537-568.

Druart, J.C. \& Straub, F. (1988): Description de deux nouvelles Cyclotelles (Bacillariophyceae) de milieux alcalins et eutrophes: Cyclotella costei nov. sp. et Cyclotella wuethrichiana nov. sp. - Schweizerische Zeitschrift für Hydrologie 50: 182-188. http://dx.doi. org/10.1007/BF02538985

Duleba, M.; Ector, L.; Horváth, Zs.; Kiss, K.T.; MolnáR, F.L.; Pohner, Zs.; Szilágyi, Zs.; Tóth, B.; VAD, Cs.F.; VÁrbíró, G. \& Ács, É. (2014): Biogeography and phylogenetic position of a warm-stenotherm centric diatom, Skeletonema potamos (C.I. Weber) Hasle and its long-term dynamics in the River Danube. Protist 165: 715-729. http://dx.doi.org/10.1016/j. protis.2014.08.001

Duleba, M.; Kiss, K.T.; Földi, A.; Kovács, J.; Kralu Borojević, K.; Molnár, L.F.; Plenković-MoraJ, A.; POHNer, Zs.; Solak, C.N.; Tóth, B \& Ács, É. (2015): Morphological and genetic variability of assemblages of Cyclotella ocellata Pantocsek/ C. comensis Grunow complex (Bacillariophyta, Thalassiosirales). - Diatom Research 30: (in press).

Economou-Amilli, A. (1979): Two new taxa of Cyclotella Kützing from Lake Trichonis, Greece. - Nova Hedwigia 31: 467-477.

Economou-Amilli, A. (1991): Cyclotella elymaea, a new fossil species from the neogene basin of Kozani-Aeani-Servia, Northern Greece. - Diatom Research 6: 223-233.

Edlund, M.B.; Williams, R.M. \& Soninkhishig, N. (2003): The planktonic diatom diversity of ancient Lake Hovsgol, Mongolia. - Phycologia 42: 232-260. http://dx.doi.org/10.2216/i0031-8884-42-3-232.1

EhrenBerG, C.G. (1845): Neue Untersuchungen über das kleinste Leben als geologisches Moment. - Bericht über die zur Bekanntmachung geeigneten Verhandlungen der Königlich-Preussischen Akademie der Wissenschaften zu Berlin 1845: 53-87.

EhrLich, A. (1966): Contribution à l'étude des gisements volcano-lacustres à diatomées de la région de Rochessauve et de Saint-Bauzile (Ardèche). - Bulletin de la Société Géologique de France, ser. 7, 8: 311-321.

Elwood, H.J.; Olsen, G.J. \& Sogin, M.L. (1985): The smallsubunit ribosomal RNA gene sequences from the hypotrichous ciliates Oxytricha nova and Stylonychia pustulata. - Molecular Biology and Evolution 2: 399-410.

Flower, R.J.; Gasse, F. \& HÅkansson, H. (1990): A new species of Cyclotella, C. azigzensis sp. nov., described from modern material collected from upland lakes in Morocco. - Diatom Research 5: 253-260. http://dx. 
doi.org/10.1080/0269249X.1990.9705117

GENKAL, S.I. (2013): Morphological variability, taxonomy, and ecology of species of the complex Handmannia comta / H. radiosa (Bacillariophyta). - International Journal on Algae 15: 331-254. http://dx.doi.org/10.1615/InterJAlgae.v15.i4.30

GeNKAL, S.I. \& BondarenKo, N.A. (2004): Electron microscopic studies of Bacillariophyta in the plankton of mountain lakes of the Lena basin. I. Centrophyceae. - Botanicheskii Zhurnal 89: 1588-1596 [in Russian].

Genkal, S.I. \& Bondarenko, N.A. (2010): Cyclotella melnikiae sp. nov., a new diatom from the mountain lakes of Pribaikalie, Russia. - Diatom Research 25: 281-291. http://dx.doi.org/10.1080/0269249X.2010.9705850

Genkal, S.I. \& BondarenKo, N.A. (2011): Diatom algae in mountain lakes of the Dzherginskiy reserve (the Baikal area). 1. Centrophyceae. - Povolzhskyi Ekologicheskyi Zhournal 2: 127-136 [in Russian].

Genkal, S.I. \& Kharitonov, V.G. (1996): Cyclotella arctica (Bacillariophyta) - a new species from Lake El'gygytgyn (Chukotka Peninsula). - Botanicheskii Zhurnal 81: 69-73 [in Russian].

Genkal, S.I. \& KulikovskiY, M.S. (2008): New centric diatom species (Bacillariophyta) from the Polistovo-Lowatsky sphagnous tract (Rdeisk State Nature Reserve). Botanicheskii Zhurnal 89: 771-775 [in Russian].

GenKal, S.I. \& KuLIKovsKIY, M.S. (2012): Cyclotella horstii sp. nov. (Bacillariophyta) from Ivankovskoe reservoir (Volga reservoirs, Russia). - Phytotaxa 59: 55-63.

Genkal, S.I. \& Kulumbaeva, A.A. (1990): About diatom algae (Centrophyceae) of Lake Song-Kyol (Western Tyan-Shan). Biologiia Vnutrennikh Vod (Biology of Inland Waters). - Informatsii Biulleten 86: 21-25 [in Russian].

Genkal, S.I. \& Kuzmin, G.V. (1979): Ultrastructura et variabilitas morphologica frustulorum Cyclotellae ocellatae Pant. (Bacillariophyta). - Novosti Sistematiki Nizshih Rastenii 16: 5-7 [in Russian].

GenKal, S.I. \& Kuzmina, A.Ye. (1989): On new species of genus Cyclotella Kütz. (Bacillariophyta). - Biology of Inland Waters 84: 9-11 [in Russian].

Genkal, S.I. \& Mikheeva, T.M. (2006): New for science species from the genus Cyclotella Kützing (Bacillariophyta). - International Journal of Algae 8: 74-77. http:// dx.doi.org/10.1615/InterJAlgae.v8.i1.70

GenKal, S.I. \& PopovsKaYA, G.I. (2008a): Morphological variability of Cyclotella ocellata from Lake Khubsulug (Mongolia). - Diatom Research 23: 75-91. http:// dx.doi.org/10.1080/0269249X.2008.9705738

Genkal, S.I. \& Popovskaya, G.I. (2008b): Centric diatom algae of the Selenga River and its delta branches. - Inland Water Biology 1: 120-128. http://dx.doi. org/10.1134/S199508290802003X

Genkal, S.I. \& Yarushina, M.I. (2004): New species of the genus Cyclotella (Bacillariophyta) from the polar Ural Lakes. - Botanicheskii Zhurnal 89: 1497-1501.

GenKAL, S.I. \& YARUSHINA, M.I. (2010): Addition of centric diatoms to the flora in waterbodies of the northern slope of the Polar Ural. - Inland Water Biology 3: 217-228. http://dx.doi.org/10.1134/S199508291003003X

Genkal, S.I. \& Zagorenko, G.F. (1987): New data about the fine structure of the valve Cyclotella ocellata Pant. (Bacillariophyta). - Biology of Inland Waters 74: 1115 [in Russian].

Genkal, S.I.; Babanazarova, O.V. \& Haffner, G.D. (2009):
New data on the flora of diatom algae (Centrophyceae) in Lake Erie (Canada). - International Journal on Algae 11: 337-350. http://dx.doi.org/10.1615/InterJAlgae.v11.i4.30

Gran, H.H. (1900): Bemerkungen über einege Planktondiatomeen. - Nyt Magazin for Naturvidenskaberne 38: $103-128$.

Greville, R.K. (1865): Descriptions of new and rare diatoms. Series XVI. - Transactions of the Microscopical Society, New Series, London 13: 43-57.

Grunow, A. (1878): Algen und Diatomaceen aus dem Kaspischen Meere. - In: SCHNEIDER, O. (ed.): Naturwissenschafte Beiträge zur Kenntniss der Kaukasusländer, auf Grund seiner Sammelbeute. - pp. 98-132, Dresden.

HÅkansson, H. (1990a): Cyclotella tripartita nov. sp. (Bacillariophyceae) and the relationship to similar taxa. - In: RicARD, M. (ed.): Ouvrage dédié à la Mémoire du Professeur Henry Germain (1903-1989). - pp. 75-82, Koeltz Scientific Books, Koenigstein.

HÅKansson, H. (1990b): A comparison of Cyclotella krammeri sp. nov. and C. schumannii Håkansson stat. nov. with similar species. - Diatom Research 5: 261-271. http://dx.doi.org/10.1080/0269249X.1990.9705118

HÅKANSSON, H. (2002): A compilation and evaluation of species in the genera Stephanodiscus, Cyclostephanos and Cyclotella with a new genus in the family Stephanodiscaceae. - Diatom Research 17: 1-139. http:// dx.doi.org/10.1080/0269249X.2002.9705534

HÅKANSSON, H. \& CARTER, J.R. (1990): An interpretation of Hustedt's terms "Schattenlinie", "Perlenreihe" and "Höcker" using specimens of the Cyclotella radiosacomplex, C. distinguenda Hust., and C. cyclopuncta nov. sp. - Journal of the Iowa Academy of Sciences 97: $153-156$.

HÅkansson, H. \& Khursevich, G. (1997): Tertiarius gen. nov., a new genus in the Bacillariophyceae, the transfer of some cyclotelloid species and a comparison to closely related genera. - Diatom Research 12: 19-33. http://dx.doi.org/10.1080/0269249X.1997.9705399

Hamsher, S.E.; Evans, K.M.; ManN, D.G.; PoulíčKovÁ, A. \& SAUNDERS, G.W. (2011): Barcoding diatoms: Exploring alternatives to COI-5P. - Protist 162: 405-422. http://dx.doi.org/10.1016/j.protis.2010.09.005

Handmann, R. (1913): Die Diatomeenflora des Almseegebiets. - Mitteilungen Mikrologischer Verein Linz 1: 4-30.

Hegewald, E. \& HindÁková, A. (1997): Variabilität von einer natürlichen Population und von Klonen des Cyclotella ocellata-Komplexes (Bacillariophyceae) aus dem Gallbergweiher, Nordwestdeutschland. - Algological Studies 86: 17-37.

Houk, V. \& KLeE, R. (2004): The stelligeroid taxa of the genus Cyclotella (Kützing) Brébisson (Bacillariophyceae) and their transfer into the new genus Discostella gen. nov. - Diatom Research 19: 203-228. http:// dx.doi.org/10.1080/0269249X.2004.9705871

Houk, V.; KleE, R. \& TAnaKa, H. (2010): Atlas of freshwater centric diatoms with a brief key and descriptions. Part III. Stephanodiscaceae A. Cyclotella, Tertiarius, Discostella. - Fottea 10 (Supplement): 1-498.

Houk, V.; KönIG, C. \& KLEe, R. (2015): Cyclotella hinziae sp. nov. - a small Cyclotella (Bacillariophyceae) from subalpine lake Schliersee (Bavaria, Germany). - Fottea 15: 235-243. http://dx.doi.org/10.5507/ 
fot.2015.021

Hustedt, F. (1922a): Bacillariales aus Innerasien. Gesammelt von Dr. Sven Hedin. - In: Hedin, S. (ed.): Southern Tibet, discoveries in former times compared with my own researches in 1906-1908. - Lithographic Institute of the General Staff of the Swedish Army, Stockholm 6 (3 Bot.): 107-152.

Hustedt, F. (1922b): Die Bacillariaceen-Vegetation des Lunzer Seengebietes (Nieder-Österreich). - Internationale Revue der gesamten Hydrobiologie und Hydrographie 10: 40-74, 233-270.

Hustedt, F. (1927): Die Diatomeen der interstadialen und stadialen Seekreide des Profils Dc (Horizonte II-IV) (Contribution pp. 317-320). - In: Gams, H. (ed.): Die Geschichte der Lunzer Seen, Moore und Wälder. Internationale Revue der gesamten Hydrobiologie und Hydrographie 18: 305-387.

Hustedt, F. (1937): Systematische und ökologische Untersuchungen über die Diatomeen-Flora von Java, Bali und Sumatra nach dem Material der Deutschen Limnologischen Sunda-Expedition. - Archiv für Hydrobiologie (Supplement) 15: 131-177, pls 9-12.

Hustedt, F. (1942): Diatomeen. - In: Thienemann, A. (ed.): Die Binnengewässer, Einzeldarstellungen aus der Limnologie und ihren Nachbargebieten von G. Huber-Pestalozzi, Das Phytoplankton des Süßwassers, Systematik und Biologie, volume 16. - pp. 367-549, E. Schweizerbart'sche Verlagsbuchhandlung, Stuttgart.

Hustedt, F. (1952): Neue und wenig bekannte Diatomeen. IV. - Botaniska Notiser 1952: 366-410.

John, J. \& Economou-Amilli, A. (1990): Cyclotella cretica, a new species of diatom from the island of Crete, Greece. - Diatom Research 5: 43-50. http://dx.doi. org/10.1080/0269249X.1990.9705091

Jones, H.M.; Simpson, G.E.; Stickle, A.J. \& Mann, D.G. (2005): Life history and systematics of Petroneis (Bacillariophyta), with special reference to British waters. - European Journal of Phycology 40: 61-87. http://dx.doi.org/10.1080/09670260400024675

JunG, S.W.; HaN, M.-S. \& KI, J.-S. (2010): Molecular genetic divergence of the centric diatom Cyclotella and Discostella (Bacillariophyceae) revealed by nuclear ribosomal DNA comparisons. - Journal of Applied Phycology 22: 319-329. http://dx.doi.org/10.1007/ s10811-009-9462-5

JuRILJ, A. (1954): Flora i vegetacija Dijatomeja Ohridskog Jezera (Flora and vegetation of diatoms from Ochrida Lake in Yugoslavia). - Jugoslavenska Akademija Znanosti i Umjetnosti, Zagreb (Prirodoslovnih istraživanja) 26: 99-190.

Kermarrec, L.; Franc, A.; Rimet, F.; Chaumeil, P.; FrigeRIO, J.-M.; Humbert, J.-F. \& Bouchez, A. (2014): A next-generation sequencing approach to river biomonitoring using benthic diatoms. - Freshwater Science 33: 349-363. http://dx.doi.org/10.1086/675079

Kharitonov, V.G. \& Genkal, S.I. (2010): Centric diatom algae (Centrophyceae) of ultraoligotrophic Lake Elgygytgyn and water bodies of its basin (Chukotka, Russia). - Inland Water Biology 3: 1-10. http:// dx.doi.org/10.1134/S1995082910010013

Kheiri, S.; NeJadsattari, T.; Asri, Y.; Hamdi, S.M.M.; SpauLding, S. \& EdLund, M.B. (2013): Cyclotella iranica sp. nov. (Bacillariophyta: Coscinodiscophyceae), a new diatom from the Karaj River, Iran. - Phyto- taxa 104: 35-42. http://dx.doi.org/10.11646/phytotaxa.104.1.5

Khursevich, G. \& Kociolek, J.P. (2012): A preliminary, worldwide inventory of the extinct, freshwater fossil diatoms from the orders Thalassiosirales, Stephanodiscales, Paraliales, Aulacoseirales, Melosirales, Coscinodiscales, and Biddulphiales. - Nova Hedwigia, Beiheft 141: 315-364.

Khursevich, G.K. \& Loginova, L.P. (1984): A new species of the genus Cyclotella (Kütz.) Bréb. from the Lower Anthropogene ancient lacustrine deposits of Belarus and Latvia. - Doklady Akademii nauk BSSR 28: $52-55$ [in Russian].

KI, J.-S.(2009): Comparative molecular analysis of freshwater centric diatoms with particular emphasis on the nuclear ribosomal DNA of Stephanodiscus (Bacillariophyceae). - Algae 24: 129-138. http://dx.doi. org/10.4490/ALGAE.2009.24.3.129

Kiss, K.T.; Rojo, C. \& Alvarez Cobelas, M. (1996): Morphological variability of a Cyclotella ocellata (Bacillariophyceae) population in the Lake Las Madres (Spain). - Algological Studies 82: 37-55.

Kiss, K.T.; Klee, R. \& Hegewald, E. (1999): Reinvestigation of the original material of Cyclotella ocellata Pantocsek (Bacillariophyceae). - Algological Studies 93: $39-53$.

Kiss, K.T.; Hegewald, E. \& Ács, É. (2002): Cyclotella hispanica a new dimorphic centric diatom species (Bacillariophyceae). Algological Studies 106: 1-16.

Kiss, K.T.; Klee, R.; Ector, L. \& Ács, É. (2012): Centric diatoms of large rivers and tributaries in Hungary: morphology and biogeographic distribution. - Acta Botanica Croatica 71: 311-363.

Kistenich, S.; Dressler, M.; Zimmermann, J.; Hübener, T.; BASTROP, R. \& JAHN, R. (2014)Aninvestigation into the morphology and genetics of Cyclotella comensis and closely related taxa. - Diatom Research 29: 423-440. http://dx.doi.org/10.1080/0269249X.2014.922125

Klee, R.; Schmidt, R. \& Müller, J. (1993): Alleröd diatom assemblages in prealpine hardwater lakes of Bavaria and Austria as preserved by the Laacher See eruption event. - Limnologica 23: 131-143.

Klee, R. \& Steinberg, C. (1987): Kieselalgen bayerischer Gewässer. - Loseblattsammlung, Informationsberichte Bayerisches Landesamt für Wasserwirtschaft 4/87, 112 pp., München.

Kling, H. \& HǍKANSSON, H. (1988): A light and electron microscope study of Cyclotella species (Bacillariophyceae) from central and northern Canadian lakes. - Diatom Research 4: 55-82. http://dx.doi.org/10.1080/0269249X.1988.9705017

KNIE, M. \& HÜBENER, T. (2007): Morphological variability of the Cyclotella ocellata-krammeri-rossii complex in field samples and cultures. - In: KusBer, W.-H. \& JAHN, R. (eds): Proceedings of the 1st Central European Diatom Meeting 2007. Berlin-Dahlem, 23-25 March 2007. - pp. 83-86, Botanic Garden and Botanical Museum Berlin-Dahlem, Freie Universität Berlin. http://dx.doi.org/10.3372/cediatom.117

Kociolek, J.P.; Laslandes, B.; Benett, D.; Thomas, E.; Brady, M. \& Graeff, C. (2014): Diatoms of the United States 1: Taxonomy, ultrastructure and description of new species and other rarely reported taxa from lake sediments in the Western U.S.A. - In: Lange-Bertalot, H. \& Kociolek, P. (eds): Biblio- 
theca Diatomologica, vol. 61. - 188 pp., J. Cramer, Gebrüder Borntraeger, Stuttgart.

Kociolek, J.P. \& Williams, D.M. (2015): How to define a diatom genus? Notes on the creation and recognition of taxa, and a call for revisionary studies of diatoms. - Acta Botanica Croatica 74: 195-210. http://dx.doi. org/10.1515/botcro-2015-0018

KorotKevich, O.S. (1959): De specibus novis Diatomacearum e Mari Barentzevii. - Botaniceskie materialy otdela sporovyh rastenij Botanicheskogo instituta imeni V.L. Komarova, Akademii Nauk S.S.S.R. Notulae Systematicae e Sectione Cryptogamica Instituti BotaniciNnomine V.L. Komarovi Academiae Scientiarum URSS 12: 88-98 [in Russian].

Kozurenko, T.F.; Loginova, L.P.; GenKal, S.I.; Chursevich, G.K. \& Sheshukova-Poretzkaja, V.S. (1992): $C y$ clotella Kütz. - In: Gleser, S.I.; MaKarova, I.V.; Moiseeva, A.A. \& Nikolaev, V.A. (eds): The Diatoms of the USSR (fossil and recent). Vol. II. Fasc. 2. - pp. 24-47, Nauka, St.-Petersburg [in Russian].

Krammer, K. \& Lange-Bertalot, H. (1991): Bacillariophyceae. 3. Teil: Centrales, Fragilariaceae, Eunotiaceae. - In: Ettr, H.; Gerloff, J.; Heynig, H. \& MolLENHAUER, D. (eds): Süßwasserflora von Mitteleuropa 2/3. - 576 pp., Gustav Fisher Verlag, Stuttgart.

KÜTZING, F.T. (1844): Die Kieselschaligen. Bacillarien oder Diatomeen. - 152 pp., 30 pls, Nordhausen.

Lange, C.B. \& Syvertsen, E.E. (1989): Cyclotella litoralis sp. nov. (Bacillariophyceae), and its relationships to C. striata and C. stylorum. - Nova Hedwigia 48: 341-356.

Loginova, L.P. (1989): Two new taxa of the genus Cyclotella (Bacillariophyta). - Botanicheskii Zhurnal 74: 1780-1782 [in Russian].

Loginova, L.P. (1990): Classification of the diatom genus Cyclotella. - In: Simola, H. (ed.): Proceedings of the Tenth International Diatom Symposium. Joensuu, Finland, August 28 - September 2, 1988. - pp. 37-53, Koeltz Scientific Books, Koenigstein.

Loseva, E.I. (1980): Novye dannye o strukture pantsirya dvukh predstavitelei roda Cyclotella Kütz. iz verkhnepliotsenovikh otlozhenii basseina $r$. Kamy (Some new data on the frustule structure of two representatives of the genus Cyclotella from Upper Pliocene deposits in Kama River basin). - Botanicheskii Zhurnal 65: 1618-1622 [in Russian].

Lowe, R.L. (1975): Comparative ultrastructure of the valves of some Cyclotella species (Bacillariophyceae). Journal of Phycology 11: 415-424. http://dx.doi. org/10.1111/j.1529-8817.1975.tb02805.x

Luddington, I.A.; Kaczmarska, I. \& Lovejoy, C. (2012): Distance and character-based evaluation of the V4 region of the 18S rRNA gene for the identification of diatoms (Bacillariophyceae). - PLoS ONE 7: e45664. http://dx.doi.org/10.1371/journal.pone.0045664

Manguin, E. (1961): Contribution à la flore diatomique de l'Alaska : Lac Karluk, espèces critiques ou nouvelles. - Revue Algologique, Nouvelle Série 5: 226-288.

McFarland, B.H. \& Collins, G.B. (1978): A key to the species of the diatom genus Cyclotella (Kütz.) Bréb., based on new morphological data. - In: Abstract, 26th annual meeting of North American Benthological Society. - p. 35, Winnipeg, Mannitoba.

Meduin, L.K.; Elwood, H.J.; Stickel, S. \& Sogin, M.L. (1988): The characterization of enzymatically amp- lified eukaryotic 16S-like rRNA-coding regions. - Gene 71: 491-499. http://dx.doi.org/10.1016/0378$1119(88) 90066-2$

Medin, L.K. \& KaczmarsKa, I. (2004): Evolution of the diatoms: V. Morphological and cytological support for the major clades and a taxonomic revision. - Phycologia 43: 245-270. http://dx.doi.org/10.2216/i00318884-43-3-245.1

Meyer, B. \& HÁkansson, H. (1996): Morphological variation of Cyclotella polymorpha sp. nov. (Bacillariophyceae). - Phycologia 35: 64-69. http://dx.doi. org/10.2216/i0031-8884-35-1-64.1

NaKov, T.; Guillory, W.X.; Julius, M.L.; Theriot, E.C. \& Alverson, A.J. (2015): Towards a phylogenetic classification of species belonging to the diatom genus Cyclotella (Bacillariophyceae): Transfer of species formerly placed in Puncticulata, Handmannia, Pliocaenicus and Cyclotella to the genus Lindavia. - Phytotaxa 217: 249-264.

Nikiteeva, T.A. \& Likhoshway, Ye.V. (1994) Cyclotella gracilis sp. nov. from Pleistocene material of Lake Baikal, Russia. - Diatom Research 9: 349-353. http://dx.doi.org/10.1080/0269249X.1994.9705312

Pantocsek, J. (1901): Die Kieselalgen oder Bacillarien des Balaton. Im Auftrage des ungarischen geographischen Gesellschaft auf Basis eigener Aufsammlungen. - In: Resultate der wissenschaftlichen Erforschung des Balatonsees. II. Band. Anhang zur II. Section des 2. Theiles. -112 pp., K. und K. Hofbuchdruckerei des Victor Hornyánszky, Budapest.

Popovskaya, G.I. \& GenKal, S.I. (2008): Materials on the flora of diatoms (Centrophyceae) from lakes of the Baikal Region and Transbaikalia. - Inland Water Biology 1: 311-319. http://dx.doi.org/10.1134/ S1995082908040019

Prasad, A.K.S.K.; Nienow, J.A. \& Livingston, R.J. (1990): The genus Cyclotella (Bacillariophyta) in Choctawhatchee Bay, Florida, with special reference to C. striata and C. choctawhatcheeana sp. nov. - Phycologia 29: 418436. http://dx.doi.org/10.2216/i0031-8884-29-4-418.1

Pruesse, E.; Peplies, J. \& Glöckner, F.O. (2012): SiNA: accurate high-throughput multiple sequence alignment of ribosomal RNA genes. - Bioinformatics 28 : $1823-1829$.

Reimann, B.E.F.; Lewin, J.M.C. \& GuIllard, R.R.L. (1963): Cyclotella cryptica, a new brackish-water diatom species. - Phycologia 3: 75-84. http://dx.doi.org/i00318884-3-2-75.1

Rimet, F.; Trobajo, R.; Mann, D.G.; Kermarrec, L.; Franc, A.; Domaizon, I. \& Bouchez, A. (2014): When is sampling complete? The effects of geographical range and marker choice on perceived diversity in Nitzschia palea (Bacillariophyta). - Protist 165: 245-259. http:// dx.doi.org/10.1016/j.protis.2014.03.005

Rodríguez, F.; Oliver, J.L.; Marín, A. \& Medina, J.R. (1990): The general stochastic model of nucleotide substitution. - Journal of Theoretical Biology 142: 485-501.

Ronquist, F.; Teslenko, M.; van der Mark, P.; Ayres, D.L.; Darling, A.; Höhna, S.; Larget, B.; Liu, L.; SuCHARD, M.A. \& HuelsenBeCK, J.P. (2012): MrBayes 3.2: Efficient Bayesian phylogenetic inference and model choice across a large model space. - Systematic Biology 61: 539-542. http://dx.doi.org/10.1093/ sysbio/sys029 
Sanger, F.; Donelson, J.E.; Coulson, A.E.; Kössel, H. \& FisCHER, D. (1974): Determination of a nucleotide sequence in bacteriophage f1 DNA by primed synthesis with DNA polymerase. - Journal of Molecular Biology 90: 315-333. http://dx.doi.org/10.1016/00222836(74)90376-3

SCHEFfler, W. (1994): Cyclotella pseudocomensis nov. sp. (Bacillariophyceae) aus norddeutschen seen. - Diatom Research 9: 355-369. http://dx.doi.org/10.1080 /0269249X.1994.9705313

Scheffler, W. \& Morabito, G. (2003): Topical observations on centric diatoms (Bacillariophyceae, Centrales) of Lake Como (N. Italy). - Journal of Limnology 62: 47-60. http://dx.doi.org/10.4081/jlimnol.2003.47

Schmid, A. (1900): Atlas der Diatomaceen-kunde. Series V (Heft 56): pls. 221-224 [F. Fricke], O.R. Reisland, Leipzig.

SCHNEIDER, O. (1878): Naturwissenschaftliche Beiträge zur Kenntniss der Kaukasuländer, auf Grund seiner Sammelbeute herausgegeben von Dr. Oscar Schneider. - 160 pp., 5 pls., Dresden. Im Verlage der Burdachschen Hofbuchhandlung. Veröffentlicht von der naturw. Gesellschaft ,Isis‘ zu Dresden.

SchÜtт, F. (1899a): Ein neues Mittel der Koloniebildung bei Diatomeen und seine systematische Bedeutung. - Bericht der Deutschen Botanischen Gessellschaft 17: 215-221.

SснÜтт, F. (1899b): Centrifugales Dickenwachsthum der Membran und extramembranöses Plasma. - Jahrbücher für wissenschaftliche Botanik 33: 470-533.

Serieyssol, K.K. (1981): Cyclotella species of Late Miocene age from St. Bauzile, France. - In: Ross, R. (ed.): Proceedings of the Sixth Symposium on Recent and Fossil Diatoms. Budapest, September 1-5, 1980. pp. 27-42, Koeltz Science Publishers, Koenigstein.

Servant-Vildary, S. (1986): Fossil Cyclotella species from Miocene lacustrine deposit of Spain. - In: RICARD, M. (ed.): Proceedings of the Eighth International Diatom Symposium. Paris, August 27 - September 1, 1984. - pp. 495-511, Koeltz Scientific Books, Koenigstein.

Solak, C.N. \& KulIKovskiY, M. (2013): Species composition and distribution of centric diatoms from Türkmen Mountain (Sakarya River Basin/Turkey). - Turkish Journal of Botany 37: 589-596. http://dx.doi. org/10.3906/bot-1204-1

Sovereign, H.E. (1963): New and rare diatoms from Oregon and Washington. - Proceedings of the California Academy of Sciences, series 4, 31: 349-368.

Tamura, K. \& Nei, M. (1993): Estimation of the number of nucleotide substitutions in the control region of mitochondrial DNA in humans and chimpanzees. - Molecular Biology and Evolution 10: 512-526.

Tamura, K.; Stecher, G.; Peterson, D.; Filipski, A. \& KuMAR, S. (2013): MEGA6: Molecular Evolutionary Genetics Analysis Version 6.0. - Molecular Biology and Evolution 30: 2725-2729. http://dx.doi. org $/ 10.1093 / \mathrm{molbev} / \mathrm{mst} 197$

Theriot, E.; HÁkansson, H.; Kociolek, J.P.; Round, F.E. \& Stoermer, E.F. (1987a): Validation of the centric diatom genus name Cyclostephanos. - British Phycological Journal 22: 345-347. http://dx.doi. org/10.1080/00071618700650411

Theriot, E.; Stoermer, E. \& HÅkansson, H. (1987b): Taxonomic interpretation of the rimoportula of freshwater genera in the centric diatom family Thalassiosirace- ae. - Diatom Research 2: 251-256.http://dx.doi.or g/10.1080/0269249X.1987.9705003

Thwaites, G.H.K. (1848): Further observations on the Diatomaceae with descriptions of new genera and species. - Annals and Magazine of Natural History, 2nd series, 1: 161-172.

Tuj, A.; Mohri, Y.; KI, J.-S.; Jung, S.W. \& Julius, M.L. (2014): Phylogeny of Praestephanos gen. nov. (Thalassiosirales, Bacillariophyceae) based on Stephanodiscus suzukii, and related freshwater thalassiosiroid diatoms. - Plankton and Benthos Research 9: 132-140. http://dx.doi.org/10.3800/pbr.9.132

Van Heurck, H. (1882): Synopsis des Diatomées de Belgique. Atlas. - pls 78-103, Ducaju \& Cie., Anvers.

Vossel, H.; Reed, J.M.; Houk, V.; CVetKoska, A. \& VAN DE VIJVER, B. (2015): Cyclotella paleo-ocellata, a new centric diatom (Bacillariophyta) from Lake Kinneret (Israel). - Fottea 15: 63-75. http://dx.doi. org/10.5507/fot.2015.006

Wawrik, B.; PAUL, J.H. \& TABITA, F.R. (2002): Real-time PCR quantification of rbcL (ribulose-1,5-bisphosphate carboxylase/oxygenase) mRNA in diatoms and pelagophytes. - Applied and Environmental Microbiology 68: 3771-3779. http://dx.doi.org/10.1128/ AEM.68.8.3771-3779.2002

Zimmermann, J.; JAHN, R. \& GemeinholZer, B. (2011): Barcoding diatoms: evaluation of the V4 subregion on the $18 \mathrm{~S}$ rRNA gene, including new primers and protocols. - Organisms Diversity and Evolution 11: 173192. http://dx.doi.org/10.1007/s13127-011-0050-6

Supplementary material

the following supplementary material is available for this article:

Fig. S1. Bayesian inferred phylogenetic tree for $18 \mathrm{~S}$ rDNA sequences constructed using Tamura 3-parameter model (TAMURA \& NEI 1993) with gamma distribution.

Fig. S2. Maximum likelihood phylogenetic tree for $18 \mathrm{~S}$ rDNA constructed using Tamura 3-parameter model (TAMURA \& NEI 1993) with gamma distribution.

Fig S3. Bayesian inferred phylogenetic tree for $r b c \mathrm{~L}$ sequences constructed using GTR model (RoDRíGUEZ et al. 1990) with gamma distribution and invariant sites.

Fig. S4. Maximum likelihood phylogenetic tree contructed using $r b c \mathrm{~L}$ sequences constructed using GTR model (RoDRíGUEZ et al. 1990) with gamma distribution and invariant sites.

This material is available as part of the online article (http:// fottea.czechphycology.cz/contents)

(C) Czech Phycological Society (2016)

Received August 21, 2015

Accepted December 21, 2015 